\title{
The Taxation of Equity, Dividends, and Stock Prices
}

\author{
Richard W. Kopcke
}

\begin{abstract}
:
The Jobs and Growth Tax Relief Reconciliation Act of 2003 (JGTRRA) essentially halved the tax rate on dividends and reduced the top tax rate on capital gains. This paper explores the likely effect of JGTRRA on the composition of returns on corporations' common stock. Both larger corporations' past behavior and theory suggest that the recent tax cuts are not likely to increase dividend payouts significantly. Instead, in the short run, dividends will continue to rise in the customary way in response to the recovery in earnings. In the longer run, the tax cuts will principally reduce companies' cost of capital, fostering capital deepening, when the economy is at full employment. With constant returns to scale prevailing at full employment, capital deepening reduces corporations' average gross return on assets and equity. Because the tax cuts increase the value of each dollar of earnings for shareholders, they could raise price-earnings ratios by more than 10 percent and stock prices by more than 6 percent. By fostering capital deepening, the tax cuts also tend to increase the real compensation of labor at full employment.
\end{abstract}

JEL Classification: H25, H71, O10

Richard W. Kopcke is a Visiting Scholar at the Federal Reserve Bank of Boston. His e-mail address is richard.kopcke@bos.frb.org.

The author thanks Maria Giduskova for her helpful assistance and Chris Foote, Bob Tannenwald, and Bob Triest for their instructive comments on early drafts of this paper.

This paper, which may be revised, is available on the web site of the Federal Reserve Bank of Boston at http://www.bos.frb.org/economic/ppdp/index.htm.

The views expressed in this paper are solely those of the author and do not reflect official positions of the Federal Reserve Bank of Boston or the Federal Reserve System.

This version: January 2005 
During the last decade of the twentieth century, the composition of returns on corporations' common stock shifted strongly away from dividends toward capital gains. This shift coincided with a substantial change in the outlook for business conditions toward a view that foresaw an especially rapid expansion of companies' investment opportunities and earnings. The shift in returns toward capital gains also followed increasing acceptance of a lesson from corporate finance: Companies can reduce their cost of capital by purchasing their stock instead of paying dividends when the tax rate on dividends exceeds that on long-term capital gains. Thus, the drop in dividend yields during the 1990s reflected some companies' switching from issuing dividends to purchasing shares, a switch made more acceptable as investors learned to appreciate a more rapid growth of earnings per share.

Since 2000, forecasts of economic growth have fallen back toward their previous historical averages. This more temperate outlook will eventually encourage companies to distribute more of their earnings to their shareholders, either by paying greater dividends or by purchasing their shares. As this modest outlook has displaced optimistic forecasts of growth, more companies probably considered maintaining, to some degree, the pace of capital gains on their equity by purchasing their stock more extensively. But in 2003, changes in federal income tax laws reduced tax rates on most dividends to match those on long-term capital gains, so that dividends and long-term gains are now taxed at about one-half the rates on short-term gains. This tax cut increased companies' incentives to distribute earnings to shareholders in the form of dividends. To the extent investors hold their shares less than a year, corporations may even reduce their cost of capital by paying dividends instead of purchasing their shares.

This paper finds that the recent reduction in the tax rate on dividends is not likely to increase dividend payouts significantly, for two reasons. First, corporations' policies for distributing earnings to their shareholders had not shifted sufficiently strongly away from dividends prior to enactment of the tax cut for the cut, by itself, to foster a substantial restoration of payments. Second, when the economy is at full employment, the tax cut will 
increase the demand for capital and reduce the aggregate earnings of corporations, thereby reducing the share of earnings available for distribution to shareholders. Nonetheless, the tax cut raises the market value of equity because it increases the value for shareholders of each dollar of corporate earnings after taxes.

Section I of this paper reviews the trends in dividends on common stock in the S\&P 500 index since the mid1940s, with particular attention to individual companies' strategies during the last two decades. Section II discusses the relationships among dividends, taxes, and the cost of capital, illustrating the benefits of purchasing shares when the tax rate on dividends exceeds that on capital gains. Section III examines the consequences of the tax cut for the cost of capital, the value of equity, and the demand for capital assets. Section IV summarizes this paper's major conclusions.

\section{Recent Trends in Dividends}

During the last ten years, the composition of returns on common stock has changed significantly, shifting away from dividends toward capital gains. From the end of World War II to 1994 , the real return on equities averaged 7.6 percent, with the dividend yield, which averaged 4.1 percent, accounting for approximately three-fifths of this return (Table 1). Subsequently, the dividend yield averaged only 1.7 percent, accounting for approximately onefifth of the 8.4 percent real return on equity. Before the mid 1990s, equities tended to appreciate at 7.5 percent annually, a rate that essentially matched the average growth rate of companies' earnings per share and of nominal GDP. Afterward, equities appreciated by 9.3 percent annually, almost twice the growth rates of earnings and GDP.

This drop in the dividend yield on equities is mainly due to the substantial increase in stock prices that occurred after the mid 1990s. Before 1995, the prices of stocks in the S\&P 500 index averaged about 14 times reported earnings. During the last ten years, this average nearly doubled. This increase in stock prices relative to earnings would have halved the dividend yield, depressing it to 2.1 percent, if companies had held constant the share of their earnings 
paid as dividends. Instead, in 2003, dividends' share of earnings was about a third lower than its prevailing value between 1947 and 1995.

The more rapid appreciation of equity not only depressed the dividend yield, but also provided shareholders the additional return to compensate for the drop in the dividend yield. Should shareholders continue to expect a total real return of near 7 percent from equities, stock prices would have to continue to appreciate at a rate more than 5 percentage points above the rate of inflation unless dividend yields rise substantially. In other words, at current dividend yields, the rate of growth of real stock prices must exceed that of potential GDP by approximately 2 percentage points.

As was the case in the 1990s, shareholders might expect companies to achieve this growth by accumulating new assets at a rapid pace, thereby boosting the growth of earnings and dividends in the future. The prospect of substantially greater dividends warrants paying a higher price per dollar of current dividends. Eventually, however, the real growth rate of companies' domestic assets must approach that of potential GDP; otherwise, diminishing returns will depress their return on assets and their earnings per dollar of equity. ${ }^{1}$ When the rapid accumulation of assets becomes uneconomical, companies can divert more of their earnings from making new investments to paying dividends. At that time, the composition of the real return on equity will shift once again, moving back toward a lower rate of appreciation and a higher dividend yield.

When opportunities for rapid growth ebb, companies can adopt a strategy that rewards shareholders with synthetic growth. ${ }^{2}$ Instead of acquiring new assets, companies can purchase their shares in public markets, thereby increasing their assets, earnings, and dividends per share of stock at rates exceeding the growth of their total assets and earnings. In these cases, the

\footnotetext{
${ }^{1}$ Although expanding abroad can extend the limits to growth, very rapid expansion for very long over a sufficiently wide area can strain the capacity of companies' managers.

${ }^{2}$ Without sufficiently profitable opportunities, companies cannot achieve higher rates of growth simply by retaining earnings to make new investments - lower dividends do not necessarily entail higher growth (see, for example, Arnott and Asness 2003).
} 
composition of real returns on corporations' outstanding equity does not shift so greatly, if it shifts at all, toward a higher dividend yield. Taken to the extreme, companies could cease paying dividends altogether, thereby compensating shareholders entirely through capital gains.

Financial theory has long suggested that corporations should purchase their shares instead of paying dividends when shareholders' tax rates on dividends exceed those on capital gains. In these circumstances, the strategy of purchasing shares makes equity more valuable to shareholders and consequently reduces companies' cost of capital. ${ }^{3}$ The drop in dividend yields and the generally low dividend payout rates during the 1990s suggest that corporations may have shifted their financial policies away from paying dividends toward purchasing their own shares. Today, three-quarters of the companies constituting the S\&P 500 pay dividends; more than nine-tenths did so in $1980 .^{4}$

\section{Corporations' Dividend Strategies}

Since 1946, the companies included in the S\&P 500 index have paid, on average, about 50 percent of their reported earnings as dividends on their common stock. This payout rate has varied considerably over the years as earnings have varied much more than dividends (Chart 1). During recessions, when earnings typically are unusually low, companies tend not to reduce their dividends commensurately because they anticipate restoring their profitability. Similarly, during years when earnings rise to unusually high levels, companies increase their dividends comparatively little because they anticipate their returns on equity returning to previous trends. ${ }^{5}$

\footnotetext{
${ }^{3}$ Black (1976), Miller (1977), Auerbach (2002), Allen and Michaely (2002), and DeAngelo and DeAngelo (2004).

${ }^{4}$ Fama and French (2001) find that the share of companies that pay dividends and appear in the Compustat database fell from two-thirds to one-fifth between the late 1970s and the late 1990s. DeAngelo, DeAngelo, and Skinner (2004) observe that the reduction in dividends is concentrated "almost entirely among firms that paid very small dividends ..."

${ }^{5}$ See Lintner (1956), Grullon and Michaely (2002), Dittmar and Dittmar (2002), Brav et al. (2003), and Koch and Sun (2004). Because managers are reluctant to cut them, dividends reflect what managers perceive as more enduring underlying trends in earnings, and managers increasingly view purchases of their companies' shares as an alternative to paying dividends. Managers are more likely to use share
} 
In view of this experience, the recent variations in payout rates for the S\&P 500 are not surprising (Chart 2). The correlations of current annual payout rates with the previous years' respective payout rates and with the growth of earnings over the previous four years, estimated from 1946 to 1990, explain the payout rates from 1991 to 2003 quite well. ${ }^{6}$ The apparent drop in payout ratios in the mid to late 1990s to rates below those of the previous five decades appears to reflect companies' customary slow adjustment of dividends to the extraordinary surge in earnings during the late 1990s. Similarly, the more recent jump and collapse of payouts corresponds to the sizable bust and boom in earnings after 2000. The data from the National Income and Product Accounts (NIPA) for dividends and profits after adjustments and taxes also show that the pre-1990 correlation between the growth of earnings and payouts forecasts the course of subsequent payout rates quite well. ${ }^{7}$

Relatively few large companies have altered their payout policies significantly over the last twenty years. For example, the 605 corporations that were included in the S\&P 500 at any time since 1985 and that currently appear in the Compustat database can be assigned to four groups according to their behavior with respect to dividend payouts (Table 2):

- No reduction in shares -77 percent did not consistently reduce the number of their outstanding shares;

- Some share purchases - 19 percent reduced their shares outstanding but did not change their dividend payout rates considerably;

- Favor share purchases - 3 percent reduced their shares outstanding and cut considerably, but did not eliminate, their payout rates;

purchases to adjust distributions of more transitory changes in earnings, particularly when they believe the price of their stock is low.

${ }^{6}$ Fitted models for both the S\&P 500 data and the NIPA data were estimated using the following equation: $\frac{D_{t}}{E_{t}}=a_{0}+a_{1}\left(\frac{D_{t-1}}{E_{t}}\right)+a_{2}\left(\frac{E_{t-1}}{E_{t}}\right)+a_{3}\left(\frac{E_{t-2}}{E_{t}}\right)+a_{4}\left(\frac{E_{t-3}}{E_{t}}\right)+a_{5}\left(\frac{E_{t-4}}{E_{t}}\right)$, where $D$ represents dividends, $E$ represents after-tax earnings, and $t$ refers to the current year.

7 The growth in 1120-S corporations and privately held corporations contributed to the upward shift in the payout ratio in the NIPA data after 1980. 
- Strongly favor share purchases - 2 percent purchased shares instead of paying a significant dividend.

This sample represents about 66 percent of the market capitalization of all domestic corporations in 2003. ${ }^{8}$ The companies in the first two groups not only substantially outnumber those in the remaining two groups but also represent more than 95 percent of the assets, earnings, and dividends of the 605 corporations in 2003. Since the 1980s, the payout ratios for the last two groups fell more substantially than those of the other groups. The payout ratio of the first group also fell considerably, but companies in that group did not reduce their outstanding shares correspondingly.

The first group comprises corporations that did not consistently use earnings to purchase their own stock in order to reduce the number of their shares outstanding. Bemis Company, for example, maintained a dividend averaging about 37 percent of earnings before extraordinary items, or 5.9 percent of book capital; its stock purchases averaged 1.8 percent of capital, and the number of its outstanding shares generally rose over the twenty years (Chart 3). This group includes companies that paid no dividends because they lacked sufficient earnings to meet their internal demands for funds and companies that cut their dividends in response to a drop in their return on capital. It also includes companies that purchased stock to prevent the number of their outstanding shares from rising too greatly as a result of their having issued warrants or granted stock options. For some, like Johnson \& Johnson (Chart 4), the number of outstanding shares did not fall over the sample period in a consistent way, suggesting that these corporations' financial strategies were balancing the pressures of several different objectives. Many of the companies in all four groups appear to have managed their capital structure, investment, and outstanding shares in a manner that produced a relatively steady increase in the book value of their capital per share. In the case of Johnson \& Johnson, capital per share rose relatively smoothly, and the ratio of dividends to operating earnings remained comparatively stable, while the number of shares fell at first and then rose in uneven steps.

\footnotetext{
${ }^{8}$ See footnote 4 .
} 
The companies in the second group tended to maintain a substantial dividend payment while reducing their outstanding shares frequently. For these companies, dividend payments exceeded the value of share purchases. Some of the companies in the second group began purchasing their shares more aggressively in the 1990s. Most, such as 3M, tended to purchase shares fairly consistently while their dividend payments were more variable (Chart 5). Although others, such as The Coca Cola Company or General Electric Company, decreased the amount of their purchases in recent years, they still reported a comparatively steady growth of book capital per share (Charts 6 and 7).

The remaining companies shifted their method of distributing gains to shareholders significantly from paying dividends toward purchasing shares. All but two of these 28 companies began purchasing their shares in the 1990s. Companies in the third group, such as IBM, significantly reduced their dividends relative to operating earnings and to book capital while they increased their purchases of shares (Chart 8). Those in the last group, such as Oracle, paid negligible dividends and relied entirely on purchases to make their equity attractive (Chart 9).

\section{Dividends, Taxes, and the Cost of Capital}

The prices that shareholders are willing to pay for common stocks reflect the yield after taxes that they require from equities (for more detail, see the Appendix, Auerbach 2002, and Allen and Michaely 2002). The higher shareholders' requirement, the lower is the price they are willing to pay for a given stream of earnings. ${ }^{9}$

The minimum rate of return corporations require of their equity capital must be

\footnotetext{
${ }_{9}$ The approach discussed here resembles the traditional view of corporate finance more closely than the new view for the reason explained in the Appendix (Auerbach 2002, pp. 1254-65). Because companies do not pursue financial strategies that simply maximize the expected value of their equity for a unique representative investor - without regard to considerations of risk, agency costs, heterogeneous assessments, and behavioral finance - they appear to adopt "interior strategies," not reaching the boundaries defined by any constraints on the payments of dividends or the net issuance of new shares (Brav et al. 2003).
} 
sufficient to cover both the yield required by shareholders and the various income tax liabilities that accrue to corporate earnings. For example, in the absence of income taxes, if shareholders required a yield of 5 percent and expected a company's stock to pay a dividend of 5 cents indefinitely, they would offer a dollar for each share (Table 3, Panel a). Companies rarely distribute all of their earnings to shareholders, however, because the normal expansion of the economy - its population, technology, and markets - allows them to retain a share of earnings in order to expand their equity while maintaining their rate of return. Assuming the economy's potential growth rate is 3.5 percent, the company's shares also would sell for a dollar if it paid a dividend of only 1.5 cents and used the remaining 3.5 cents to make new investments, expanding its equity capital every year in this manner, thereby increasing its stock price and dividend at an annual rate of 3.5 percent indefinitely. In this second instance, as the stock price rises at the same rate as dividends, the sum of the dividend yield and the capital gain will equal the required 5-percent yield.

The required yield reflected in the pricing of equity sets the standard for the returns that companies expect to earn on their equity capital. Continuing the previous examples, the 5percent yield required by shareholders entails a 5-percent cost of equity for the company. In the first case (dividend payout only), if the company were to consider issuing new shares to acquire assets that yielded only a 4-percent return on equity capital, it would be diluting its ability to pay a 5-cent dividend with each new share that it issued. This dilution would depress its dividend and, with it, the value of its equity.

In the second case (dividends plus growth), the company retains a portion of its 5percent return on equity capital in order to expand, reinvesting shareholders' earnings on their behalf. If the return on these new assets were only 4 percent, the company would again be diluting its ability to both pay a dividend equal to 1.5 percent of its equity capital and retain sufficient earnings to increase its equity capital by 3.5 percent annually. By reinvesting earnings equal to 3.5 percent of equity capital in projects that returned only 4 percent, the company would have acquired assets that would contribute only a 0.5-percent yield toward dividends. 
The price of the company's shares would fall as the return on these shares would drop below the yield required by shareholders. Conversely, should the company earn 6 percent on its new investment, it would be able to pay a 2.5-percent dividend while retaining sufficient earnings to continue growing at 3.5 percent. In these circumstances, as the new investments lifted dividends and the total return to shareholders, the value of the company's shares would rise above one dollar.

Companies typically distribute a portion of their earnings to their shareholders when they lack opportunities to reinvest these earnings at the yields required by their shareholders. ${ }^{10}$ In the previous examples, each dollar of earnings that a company either distributes to its shareholders or reinvests at a return that matches or exceeds its shareholders' required yield is worth at least a dollar. Each dollar of earnings that it reinvests at an insufficient rate of return is worth less than a dollar to its shareholders and depresses the market value of its equity. Consequently, a dollar of earnings that the company distributes to its shareholders is more valuable than a dollar of retained earnings when its return on new investments is below its cost of equity.

\section{Consequences of Corporate and Personal Income Taxes}

A corporation's cost of equity exceeds its shareholders' required yields by a margin that reflects the income tax liabilities shareholders incur on their capital gains and dividends. The additional return on equity capital needed to cover these liabilities ordinarily reduces a company's demand for capital assets because the return on marginal investment projects falls as it expands its scope or scale of operations. This requirement to earn a higher rate of return does not necessarily reduce a company's growth rate over time because, however extensive its assets, its investment opportunities continue to grow with the normal expansion of the economy without diminishing its return on assets.

\footnotetext{
${ }^{10}$ The payment of dividends also mitigates significant agency problems that can arise when managers accumulate funds in the absence of investment opportunities and when shareholders cannot monitor their use of these funds sufficiently closely. See Shefrin and Statman (1984) and DeAngelo, DeAngelo, and Stulz (2004).
} 
Shareholders pay a variety of tax rates on their dividends and capital gains. For people who hold equities either for many years or in tax-deferred accounts, these effective tax rates can be negligible. ${ }^{11}$ For others in high tax brackets who trade equities frequently, these tax rates are more substantial. For equities to appeal to affluent investors who trade stock without the benefits of tax shelters, the returns on equity must be sufficient to cover both their required returns and their personal tax liabilities. Because affluent investors actively trade stocks, the effective marginal tax rates on dividends and capital gains reflect the tax liabilities of investors in higher tax brackets (Table 4).

A capital gains tax is likely to raise the cost of equity most for companies that grow most rapidly, because capital gains account for a relatively high proportion of the return on equity for shareholders of these companies (Table 3, Panel b). With an 18.9-percent effective marginal tax rate on capital gains, the cost of equity remains at 5 percent in the first case, when the company earns a net return of 5 percent on its equity capital and distributes all of its earnings as dividends. But, in the second case, when the company pays a 1.5 percent dividend and grows by 3.5 percent annually, shareholders receive a net capital gain of only 2.8 percent and a net total return of only 4.3 percent. Consequently, shareholders would bid only 68 cents for each dollar of the company's equity capital. This price would provide shareholders with a dividend yield of 2.2 percent, which, combined with their net capital gain of 2.8 percent, would meet their required yield of 5 percent. The capital gains tax has raised the cost of equity in this case. The company must now earn a net return of 5.7 percent on its equity capital -2.2 percent for dividends and 3.5 percent for expansion - in order for a dollar of its equity capital to sell for one dollar in equity markets.

\footnotetext{
${ }^{11}$ Because long-term capital gains (currently, equity held longer than one year) are taxed at one-half of ordinary income tax rates for most taxpayers, those who retain their stocks for lengthy periods can reduce their effective tax rate considerably. Shareholders can also avoid paying current dividend and capital gains taxes, even on equities they retain less than one year, by holding their stocks in tax-sheltered annuity, retirement, or life insurance accounts. The payments from these accounts are taxed at ordinary income tax rates at the time shareholders eventually receive these payments. In the interim, shareholders earn a return on their deferred tax liabilities. Shareholders can also avoid capital gains taxes by donating their shares, in place of cash, to qualifying charities, public service institutions, or religious organizations. Shares held until their owners die incur no capital gains tax, because heirs have the opportunity to transfer them to their ownership at prevailing market values (the "step-up in basis" at death allowance).
} 
A positive rate of inflation increases the effective tax rate on shareholders' real capital gains, because stock prices tend to rise over time as earnings and dividends increase with the prices of goods and services (Table 3, Panel c). In the previous example, an inflation rate of 2 percent would increase the nominal growth of capital, dividends, and share prices from 3.5 percent to 5.5 percent. After capital gains taxes, however, shareholders' real capital gain would fall to 2.5 percent $(=5.5 *(1-.189)-2)$. In order for shareholders to receive the 5 -percent real after-tax return that they require, the company would need to pay a 2.5-percent dividend, which would require the company to earn a net return on equity capital of 6 percent.

A dividend tax, in combination with the capital gains tax, further increases the cost of equity capital (Table 3, Panel d). With a 27.8-percent dividend tax, the company must pay a 3.5percent dividend for shareholders to receive the after-tax payment of 2.5 percent that they require. If the company earns a net return on capital of 7 percent, it can pay this dividend while retaining 3.5 cents per dollar of capital for expansion.

\section{Issuing Dividends versus Purchasing Shares}

When a company purchases its shares instead of paying dividends, it substitutes the capital gains tax rate for the dividend tax rate on the earnings it distributes to shareholders. ${ }^{12}$ As a result, companies can reduce the tax liabilities of their shareholders, thereby reducing their cost of equity when the tax rate on dividends exceeds that on capital gains. If the company in the previous example omitted its dividend and purchased its shares instead, its shareholders would receive nominal capital gains at the rate of 9 percent: 5.5 percent as before plus 3.5 percent due to the increase in equity capital and earnings per share resulting from the reduction in outstanding shares. Accordingly, shareholders' after-tax returns would rise to 5.3 percent $(=9 *(1-.189)-2)$. By paying no dividends, the company can reduce its cost of capital from 7.0 percent to 6.7 percent and still meet shareholders' required rate of return of 5.0 percent.

\footnotetext{
${ }^{12}$ This paper takes the "traditional view" of the cost of capital for equity instead of the "new view." See

"The Effect of Taxes on the Cost of Capital"in the Appendix to this paper.
} 


\section{The Cost of Capital and the Tax Cut of 2003}

The Jobs and Growth Tax Relief Reconciliation Act of 2003 (JGTRRA) essentially halved the dividend tax rate and reduced the top tax rate on capital gains. ${ }^{13}$ Although this tax cut should raise stock prices and lower the cost of equity, it alone is not likely to raise dividend payments very sharply, very soon. Corporations' distribution policies did not shift sufficiently away from the payment of dividends toward share purchases for the tax cut, by itself, to foster a substantial restoration of payments. Just as tax policies appear to have been of secondary concern for payout policies in the past, recent changes in economic conditions are likely to dominate companies' dividend strategies. In the short run, dividend strategies will reflect companies' responses to a variety of influences, some more forceful than the tax cut, including pressing needs for liquidity or working capital. In the longer run, the drop in the cost of capital resulting from the tax cut will tend to reduce companies' average return on equity capital while increasing their capital budgets, thereby reducing the share of earnings available for distribution to shareholders.

Among the companies included in the S\&P 500 index during the last two decades, those that would likely show most clearly a specific response to the tax cut are the 28 companies that both reduced their dividend payouts from earnings and purchased their shares (Table 2). Through 2003, of the 13 companies that strongly favored share purchases by essentially omitting their dividend, none began paying out a substantial portion of earnings. Dividends of Federated Department Stores, for example, remained very small, although the company did increase its dividend distribution in 2003 (Chart 10). Similarly, Handleman Company initiated a small payment in 2003. Of the 15 companies that favored share purchases while maintaining a more substantial dividend, only International Game Technology reduced its purchases and increased its dividend payout rate substantially, with respect to both earnings and book capital, as its outstanding shares began to stabilize or rise (Chart 11).

\footnotetext{
${ }^{13}$ The Act limits the maximum tax rates on dividends and long-term capital gains to 15 percent for investors not subject to the Alternative Minimum Tax.
} 
For the S\&P 500 as a whole, the growth of earnings during the coming quarters will probably have more impact than the tax cut on dividends and stock prices. Currently, the data suggest that dividends are rising as expected with the recent strong growth of earnings and that dividends have yet to increase significantly in direct response to the tax cut. ${ }^{14}$ Dividends rose 14 percent through the first three quarters of 2004 compared with the comparable period in 2003, while earnings increased by about 25 percent, so that dividends relative to earnings fell by about 3 percentage points. This result essentially matches corporations' typical behavior as discussed in the first section of this paper (see the discussion of Chart 2). The customary response of dividends to a surge in earnings of the magnitude that occurred in 2002 and 2003 predicts a dividend payout ratio of 36 percent for 2004; the average during the first three quarters of the year was 32 percent.

Using National Income and Product account data rather than S\&P 500 data, the customary response of dividends to the recent growth in profits predicts a payout rate near 45 percent in 2004. During the first three quarters of the year, the payout rate averaged 46 percent.

As earnings decelerate through 2005, dividends will rise more rapidly than earnings for the S\&P 500 if they follow the historical relationship. If earnings grow by 10.6 percent in 2005, as analysts surveyed by Thompson Financial/First Call currently expect, the historical relationship predicts that dividends will rise by 25 percent and the payout rate will rise to 39 percent.

Beyond the course of earnings, other motives could shape dividend strategies in coming quarters more than the tax cut (Brav et al. 2003). ${ }^{15}$ To the extent that these other influences deviate from their customary cyclical patterns, they could alter the typical response in payout rates. Companies' financial executives believe that retail investors value dividends, and the

\footnotetext{
${ }^{14}$ See also Blouin, Raedy, and Shackelford (2004). Chetty and Saez (2004), using the Center for Research in Securities Prices data set, estimated the probability of a company's initiating regular dividends or increasing its dividend. They found that the "...tax reform induced a large, widespread set of firms to initiate regular dividend payments or raise the payments that they already were making." (p. 21). But, in an apparent reflection of the findings of DeAngelo, DeAngelo, and Skinner (2004), companies that paid very small dividends likely accounted for the preponderance of these payments, a conclusion that is consistent with the data shown in Table 2 and Chart 2.

${ }_{15}$ See also Shefrin and Statman (1984) and DeAngelo, DeAngelo, and Stulz (2004).
} 
recent relatively strong performance of equities that pay dividends could reinforce incentives for increasing dividends. ${ }^{16}$ On the other hand, the lower cost of equity and the recovery in economic activity will likely increase companies' demands for liquidity and working capital, and these demands would tend to restrain their payment of dividends. This is especially relevant now that companies' tax liabilities will tend to rise in the wake of the expiration of key provisions of the Economic Growth and Tax Relief Reconciliation Act of 2001 and JGTRRAprovisions that allowed companies to accelerate substantially their depreciation allowances on assets acquired before the end of 2004. Companies are indeed reporting unusually high cash positions on their balance sheets, and these positions have continued to increase throughout the year. Finally, the lower cost of equity resulting from the dividend tax cut may also encourage companies for a time to apply earnings toward the retirement of debt, substituting equity for debt financing. ${ }^{17}$

\section{The Tax Cut's Longer-Term Consequences}

In time, companies' financial strategies will reflect the tax cuts on dividends and capital gains as well as their opportunities for growth and their rates of return on capital. From this longer-term perspective, companies' dividends and stock prices will depend more on the outlook for earnings than on the tax cut itself. If the prospect for growth resembles the moderate view that prevailed in the 1970s or 1980s, rather than the more aggressive view that prevailed in much of the 1960s and 1990s, the composition of returns on equity will shift away from capital gains toward dividends. Otherwise, the composition of returns will likely continue to favor capital gains.

From a company's viewpoint, the tax cut reduces the cost of equity. It also increases stock prices and could increase dividends paid per share even if the company pays a smaller

\footnotetext{
16 Through November 30, 2004, the total return on stocks that pay dividends in the S\&P 500 averaged 14.4 percent, while the total return for the remainder averaged 7.8 percent (S\&P 2004).

${ }_{17}$ A reduction in cost of equity relative to debt could induce companies to reduce their targets for leverage. This shift, which reduces the degree of financial risk in companies' capital structures, would reduce the cost of equity and the return on equity capital somewhat more over the long run.
} 
share of its earnings as dividends. The extent of the increase in the company's stock price and dividends per share depends on its opportunities for expanding profitably its scale and scope of operations.

Consider the prior example of a company whose shareholders require a 5 percent real after-tax return on equity, entailing a 7 percent cost of equity to the company (Table 3, Panel d). Suppose JGTRRA reduced its shareholders' effective capital gains tax rate to 14.1 percent and their effective tax rate on dividends to 13.7 percent (Table 4). Because the company's equity capital, dividends, and share prices tend to rise by 5.5 percent annually and the inflation rate is 2 percent, shareholders would earn a real after-tax return of 2.7 percent (5.5(1-.141)-2=2.7) from capital gains. Therefore, they would require an after-tax dividend yield of 2.3 percent. Considering the cut in the dividend tax rate, the company must pay only a 2.6-percent (2.6(1$.137)=2.3$ ) dividend to meet this requirement. In order to pay that dividend and still retain 3.5 cents per dollar of equity capital to finance its expansion, the company must earn a net return on equity capital of 6.1 percent (Table 3, Panel e). Therefore, its cost of equity would fall by almost one percentage point from the pre-tax-cut scenario.

The consequences of this reduction in the cost of equity will depend on the company's willingness and ability to respond. If it maintained its net return on capital at 7 percent and continued to pay a 3.5-percent dividend, its dividend payout rate would not change. Both the price of the company's stock and the amount of its dividend after taxes would rise by 33 percent, and shareholders would still earn a net dividend yield of 2.3 percent. If, on the other hand, the company expanded in response to the drop in its cost of equity, its dividend payout rate would fall, and its stock price would increase further. Its equity capital and dividends per share, like its stock price, would increase by amounts that depend on the volume of profitable investment opportunities resulting from its lower cost of equity. 
Companies typically finance the expansion of their equity capital by boosting, for a time, their retained earnings. ${ }^{18}$ In this example, the company would do so until the return on new additions to its equity capital fell to 6.1 percent. Each dollar of these additional retained earnings would be worth at least a dollar to its shareholders as long as the dollar contributed at least 6.1 cents to earnings. Once this temporary expansion was complete, the company's payout rate would remain lower than it had been before the tax cut because its average net return on equity capital would have fallen while its requirements for financing its continuing growth would have remained at 3.5 percent of equity capital. ${ }^{19}$ Dividends per share would have risen, however, because equity capital and earnings per share would have increased as a result of the extraordinary retention of earnings. Each share would receive the dividend that it would have received without the extraordinary retention plus the dividend from the new equity capital and its earnings resulting from this extraordinary retention. This additional equity capital and earnings would increase the value of each share beyond the initial 33 percent.

Ultimately, the extent of the increase in stock prices and dividends per share will depend both on the volume of investment opportunities that offer returns between 7 percent and 6.1 percent and on the average rate of return on these new investments. The more extensive are the new opportunities and the longer the average return on these new opportunities remains near 7 percent before falling to 6.1 percent, the more dividends per share and stock prices will increase. The consequences for companies of the lower tax rates, therefore, will vary across corporations, depending on their opportunities for expansion and on the differences between their average and marginal returns on capital.

\section{The Macroeconomic Point of View}

We can estimate the longer-run consequences of the tax cut for all companies by

\footnotetext{
${ }^{18}$ By selling new shares, the company would dilute the claims of existing shareholders to any rents on both existing and new investments. Companies may issue new shares when these rents are relatively small or the opportunities for new investments are particularly large and urgent.

${ }^{19}$ If the transition takes very long or increases the long-run rate of growth, then the payout ratio could fall considerably in response to the cut in dividend taxes.
} 
applying this analysis to the entire economy. As in the examples above, the tax cuts reduce the cost of equity, which in turn reduces the cost of capital and increases the demand for capital assets. In assessing the consequences of the tax cuts, the macroeconomic view recognizes economy-wide constraints on the supplies of resources, especially labor. Competition for resources and markets tempers companies' abilities to expand profitably when the economy is at full employment; new investments often reduce returns on existing assets. A production function, which defines the relationship between output and the supplies of capital and labor, describes the increase in the demand for capital assets in response to the drop in the cost of capital. The expansion of the domestic labor force and the rate of technological change in the domestic production function define the prospects for growth. Together, these elements determine the aggregate employment of capital assets, the return to equity capital, the dividend payout rate, and the value of equity at full employment (see the Appendix, Auerbach 2002, Gravelle 2003, and Mankiw and Weinzierl 2004).

The standard macroeconomic analysis differs considerably from that for a specific company in two important ways. First, production functions for an entire economy typically enforce constant returns to scale. Accordingly, the average and marginal returns to capital assets are equal in equilibrium - companies earn no economic rents. Second, when the economy is at full employment, it cannot alter greatly its scope or scale of operations in response to a change in the cost of equity; instead, it changes the stock of capital assets employed per laborer. Higher capital-labor ratios entail lower marginal returns to capital assets, and the extent to which these returns fall as the capital-labor ratio rises depends on the degree to which capital services can substitute for labor services. The higher is this elasticity of substitution, the more the use of capital assets responds to a change in the cost of capital. Just as the return on capital assets falls with the higher capital-labor ratio, the compensation of labor services rises, because labor becomes scarcer relative to capital assets.

The tax cuts of 2003 likely reduced the economy-wide cost of equity by between 50 and 100 basis points (Table 5, upper panel). As illustrated in the previous examples, the cost of 
equity depends on shareholders' required real rate of return, the inflation rate, the potential real growth rate of business opportunities, the share of dividends allocated to stock purchases, and the tax rates on dividends and capital gains. The pricing of the equities constituting the S\&P 500 suggests that shareholders' required real return on equity has been between 4 percent and 6 percent during much of the last half century (Kopcke and Rutledge 2004). We assume that expectations of long-term inflation are 2.5 percent. ${ }^{20}$ We consider two rates of growth of business opportunities: 3.25 percent, which matches lower estimates of the economy's potential rate of growth; and 4 percent, which allows for a more rapid growth of productivity or companies' ability to expand abroad. ${ }^{21}$ We assume that companies allocate 15 percent of earnings to purchase equity. ${ }^{22}$ Finally, JGTRRA reduces the marginal effective tax rates on dividends and capital gains, respectively, from 27.8 percent to 13.7 percent and from 18.9 percent to 14.1 percent (Table 4). With 3.25 percent growth, the net return on equity capital before JGTRRA would have been 7.05 percent in order to cover shareholders' required real after-tax return of 5 percent (Table 5, upper panel). After JGTRRA, companies' net return on equity falls 83 basis points to 6.22 percent. About one-half of this drop can be attributed to the cut in the dividend tax rate..$^{23}$

This reduction in the cost of equity likely reduced the required return on capital assets (net income plus interest expense divided by total assets) by between 60 and 100 basis points

\footnotetext{
${ }^{20}$ The Survey of Professional Forecasters' current forecast for long-term inflation is 2.5 percent.

${ }^{21}$ The analysts surveyed by Thompson Financial expect real earnings for corporations to grow at about twice the rate of potential GDP for the next five years.

${ }^{22}$ For the S\&P 500, the net purchases of equity as a percent of income before extraordinary items ranged between 12 percent and 25 percent from 1995 to 2003 (versus -2 percent to 15 percent from 1985 to 1994) and has remained near 15 percent since 2000. This measure includes purchases by companies in order to limit the increase in their outstanding shares that resulted from the exercise of warrants and options that they had issued. Consequently, this measure overstates the extent to which companies purchase their equity in order to increase their assets and earnings per share; so, it understates the consequences of a dividend tax cut and overstates the consequences of a capital gains tax cut. See footnotes 22 and 27. ${ }^{23}$ If shareholders expect companies to distribute earnings only as dividends, then when growth equals 3.25 percent and the shareholders' required return equals 5 percent, the cost of equity drops 96 basis points from 7.18 percent to 6.54 percent, and the dividend tax cut accounts for about two-thirds of this drop.
} 
(Table 5, lower panel). ${ }^{24}$ We assume that equity capital represents 64 percent of all capital assets, ${ }^{25}$ that the effective marginal corporate income tax rate is 30 percent, and that the real cost of debt is 1.8 percent. ${ }^{26}$ With a 3.25 percent rate of growth, corporations' required rate of return on total capital - equal in equilibrium by accounting identity to the cost of capital - would need to have been 7.11 percent to provide shareholders a real after-tax return on equity of 5 percent before JGTRRA. Afterward, corporations' required rate of return fell 76 basis points to 6.35 percent.

As a result of this drop in required returns, the equilibrium stock of capital assets increases by between 3 percent and 6 percent, while equilibrium earnings fall by between 6 percent and 7 percent (Table 6). The response of the demand for capital assets to the drop in the cost of capital depends on the extent to which capital assets can substitute for labor in the production function. The greater this elasticity of substitution, the more the demand for these assets increases in response to a reduction in the cost of capital. Common estimates of the elasticity of substitution equal one or less (for example, see Antras 2004). When this elasticity is one, the demand for capital assets varies inversely with the cost of capital plus the rate of depreciation of capital assets. When the elasticity is less than one, demand is less responsive. Because the rate of depreciation of capital assets is 9 percent, ${ }^{27}$ a drop in the cost of capital from 7.11 percent to 6.35 percent increases the demand for capital assets by only 4.7 percent if the elasticity is one, growth is 3.25 percent, and shareholders require a return of 5 percent.

With constant leverage, equity capital increases in proportion with capital assets. Accordingly, the tax cuts that reduce the cost of equity by 11.8 percent increase equity capital by only 4.7 percent, and the net return to equity capital - which in equilibrium equals the product

\footnotetext{
${ }^{24}$ The analysis assumes constant leverage. If leverage falls, as mentioned in footnote 16, the resulting reduction in the return on equity capital and increase in the demand for capital (as discussed below) would tend to diminish companies' capacity for paying dividends.

${ }^{25}$ Compustat reports that the ratio of debt to assets for the S\&P 500 was 35.8 percent for year-end 2003.

${ }^{26}$ Currently the yield on A corporate bonds is 6.2 percent, which, net of corporate taxes at a 30 percent marginal rate and net of an inflation premium of 2.5 percent, provides a real return of 1.8 percent. 27 The consumption of fixed capital for corporate businesses averaged 8.7 percent of the current cost of the net stock of fixed assets for corporate businesses for 2002 and 2003.
} 
of the cost of equity and the quantity of equity capital, average net income - falls by 7.04 percent (Table 6, lower panel).

Finally, the tax cuts raise the equilibrium price-earnings ratio for equities by between 10 percent and 14 percent, and the total market value of equity by between 4 percent and just over 7 percent (Table 7). Although the net returns to equity capital fall, JGTRRA substantially increases the after-tax value of each dollar of these earnings for shareholders. If shareholders require returns of 5 percent and growth is 3.25 percent, the price-earnings ratio for equity rises by 13.3 percent, with the cut in dividend taxes accounting for just over one-half of this increase (Table 7, upper panel). The increase in the price-earnings ratio more than offsets the drop in aggregate earnings to raise the total market value of equity by 6.3 percent (Table 7, lower panel). ${ }^{28}$

\section{Conclusion}

The Jobs and Growth Tax Relief Reconciliation Act's reduction of dividend and capital gains taxes reduces the cost of capital for businesses. Consequently, this tax cut will increase companies' demand for capital assets when the economy is at full employment, thereby reducing the average return on these assets while increasing the compensation of labor. In the short run, the share of earnings that companies pay as dividends on their common stock probably will not change significantly as a result of JGTRRA. Instead, dividends will reflect the course of earnings and companies' needs for liquidity. In time, JGTRRA will tend to reduce the share of earnings that companies pay as dividends, because, with lower average rates of return on equity capital, the requirements for financing future growth will account for a higher proportion of earnings.

Although JGTRRA's tax cuts will tend to depress aggregate before-tax corporate

\footnotetext{
${ }^{28}$ If shareholders expect companies to distribute earnings only as dividends, then when growth equals 3.25 percent and the shareholders' required return equals 5 percent, the price-earnings ratio rises by 15.5 percent and the market value of equity rises by 7.5 percent, with the dividend tax cut accounting for almost two-thirds of these increases.
} 
earnings at full employment, they increase the market value of equities. With constant returns to scale, the tax cuts will reduce the average return on equity capital by an amount that matches the reduction in the cost of equity. Common estimates of the extent to which capital can substitute for labor imply that the demand for capital at full employment will not increase sufficiently to offset this drop in the average return on equity capital. Consequently, JGTRRA will tend to reduce earnings and dividends per share of stock. For those companies that can maintain a sufficiently large share of their former return on previously installed capital assets while they expand, average rates of return on equity capital will increase, lifting both earnings and dividends per share. In any case, the tax cuts increase the market value of equities, even if they reduce earnings, because the net value of earnings rises for shareholders: The drop in earnings is more than offset by the increase in price-earnings ratios.

As a result of the tax cuts on dividends and capital gains, both average real returns on equity and dividend yields need not be as high as they were during much of the last half century. Unless the economy's potential rate of growth or rate of inflation is significantly higher than current estimates, about 3.5 percent and 2.5 percent, respectively, the composition of returns on equity will shift toward dividends once again, albeit not as strongly as before 1994 . For example, before 1994, real returns on equity averaged 7.6 percent and dividend yields averaged 4.1 percent, together providing marginal shareholders an after-tax real return of less than 5 percent. After JGTRRA, with the current outlook for economic growth and inflation, total real returns on equity averaging only 6.2 percent, including a dividend yield of 2.7 percent, would provide shareholders an after-tax real return of 5 percent. 


\section{Appendix}

\section{Theoretical Model of the Value of Dividends and Equity}

This section develops and extends the Gordon model of stock prices, in which shareholders value a corporation's equity according to the rate of growth of its earnings and dividends, its prospective return on capital, and the capital gains on its stock, which, in turn, depend on the growth of the assets and earnings that back its shares. Earnings benefit shareholders directly when companies distribute a portion as dividends, less directly when companies use their earnings to purchase new assets or buy back stock in order to increase the assets and earnings behind each share. This reinvestment of earnings commonly rewards shareholders with capital gains, because the price of stock ordinarily rises with the promise of greater earnings and dividends.

In valuing equity, shareholders consider the dividends they expect to receive while they hold their stock and the capital gains they anticipate receiving when they sell. The price others will be willing to offer for shares in the future will be governed by these future investors' assessments of their dividends and capital gains, which, in turn, will reflect the present value of dividends and capital gains that subsequent investors might expect. This chain of logic implies that shareholders value their equity by discounting prevailing estimates of all future dividends; by doing so, they take into account the growth of the value of assets behind each share. This approach emphasizes the correspondence between the price of stocks and their earnings.

Companies' earnings equal the value of their capital (assets less liabilities) multiplied by their net return on capital (after capital consumption expenses, corporate income taxes, and other business taxes),

$$
E=r \cdot C
$$

As a result of the normal expansion of the economy and markets, companies' opportunities for making new investments allow their capital and earnings to grow at rate $\gamma$ while maintaining 
their rate of return. The average company cannot grow more rapidly without eventually depressing its return on capital-the resulting expansion of the company's scope or its greater capital deepening would reduce its return on new investments. The value of assets and their earnings also increase as a result of inflation, $\pi$. Other things being equal, shareholders generally expect earnings to grow, on average, at rate $\gamma+\pi$. To maintain their leverage, companies increase their capital at the same rate by retaining a portion of their earnings, a portion that tends to rise with the rate of growth of opportunities for profitable investments and fall as the net rate of return on capital rises,

$$
\alpha=\gamma / r \text {. }
$$

Companies distribute the remainder of their earnings to shareholders, either by paying dividends, $D$, or by purchasing their own stock.

The shareholders' real discount rate is the sum of the real risk-free rate of interest, $\rho$, and the risk premium, $p$, they require for holding equity. The real risk-free rate is the nominal riskfree rate of interest, $i$, less taxes and the inflation premium, $\pi$.

The shareholders' real discount rate, $\delta$, is therefore

$$
\begin{aligned}
& \rho=i(1-t)-\pi \\
& \delta=\rho+p .
\end{aligned}
$$

Suppose companies distribute the earnings only by paying dividends and do not purchase their own stock,

$$
D=(1-\alpha) E .
$$

If dividends are taxed at rate $t_{d}$, capital gains are taxed at effective rate $t_{c}$, and equity appreciates at rate $\gamma+\pi$, then for equity to yield the required real rate of return $\delta$, its market value is 


$$
\begin{aligned}
P & =D\left(1-t_{d}\right) \int_{0}^{\infty} e^{(\gamma+\pi) s} e^{-(\delta+\pi) s} d s-P(\gamma+\pi) t_{c} \int_{0}^{\infty} e^{(\gamma+\pi) s} e^{-(\delta+\pi) s} d s \\
& =D\left(1-t_{d}\right) /(\delta-\gamma)-P(\gamma+\pi) t_{c} /(\delta-\gamma) \\
& =\frac{D\left(1-t_{d}\right)}{\delta-\gamma+(\gamma+\pi) t_{c}} \\
& =\frac{(1-\alpha) E\left(1-t_{d}\right)}{\delta-\gamma+(\gamma+\pi) t_{c}} \\
& =\frac{(r-\gamma) C\left(1-t_{d}\right)}{\delta-\gamma+(\gamma+\pi) t_{c}} .
\end{aligned}
$$

The market value tends to rise with capital, but, as capital increases, the average return on capital, $r$, tends to fall as a result of decreasing returns or diminishing profits on new projects.

The dividend yield, price-earnings ratio, and market capitalization relative to the replacement value of capital are

$$
\begin{aligned}
& \frac{D}{P}=\frac{\delta-\gamma+(\gamma+\pi) t_{c}}{\left(1-t_{d}\right)} \\
& \frac{P}{E}=\frac{1}{r} \cdot \frac{(r-\gamma)\left(1-t_{d}\right)}{\delta-\gamma+(\gamma+\pi) t_{c}} \\
& \frac{P}{C}=\frac{(r-\gamma)\left(1-t_{d}\right)}{\delta-\gamma+(\gamma+\pi) t_{c}}
\end{aligned}
$$

For viable companies, equity should be worth at least as much as the value of capital $\left(\frac{P}{C} \geq 1\right)$, implying

$$
\begin{gathered}
r \geq \frac{\delta+\pi t_{c}-\gamma\left(t_{d}-t_{c}\right)}{1-t_{d}} \square r_{\min } \\
r-\delta \geq \frac{\delta t_{d}+\pi t_{c}-\gamma\left(t_{d}-t_{c}\right)}{1-t_{d}}=r_{\min }-\delta .
\end{gathered}
$$

The difference between the average return on capital and shareholders' required return on equity increases with the tax rates on dividends and capital gains.

This difference also depends on the degree to which returns on new investments fall as capital increases. With perfect competition, constant returns to scale, and negligible friction for 
undertaking investments and obtaining financing, the difference between companies' average return on capital and shareholders' required returns would attain its minimum - that dictated by tax rates on dividends and capital gains. Without these conditions, the average return on capital would exceed the minimum and the return on new additions to capital. Companies attempt to equate the marginal return on capital with the minimum return. If the marginal return exceeds the minimum, companies could use a dollar of earnings to acquire capital that shareholders would value more than a dollar. The net return on marginal capital can be no lower than the minimum allowed by the equation above; otherwise, shareholders would value each dollar of new capital less than one dollar in equity markets.

The difference between average returns on capital and required returns on equity can be greater than the minimum if a company's earnings are not sufficient to allow it to pursue all investments that offer acceptable returns. If the company were to issue new stock to raise sufficient capital, it would reduce its earnings per share and the price of each share of its stock as the number of its shares rose while its average return on capital fell.

\section{Paying Dividends versus Purchasing Shares}

When the tax rate on dividends exceeds that on capital gains, companies can increase their net returns to shareholders and therefore their share prices by repurchasing their stock instead of paying dividends. If a company reduced its dividend by proportion $\varphi$ of earnings and used the money to repurchase its stock instead, it would reduce the number of its outstanding shares and increase its assets per share by the proportion $\varphi E / P$. If it maintained this policy, the rate of growth of assets per share would be $\alpha r+\pi+\varphi E / P$, and the price of its stock would be 


$$
\begin{aligned}
P & =D\left(1-t_{d}\right) \int_{0}^{\infty} e^{\left(\alpha r+\pi+\varphi \frac{E}{P}\right)\left(1-t_{c}\right) s} e^{-(\delta+\pi) s} d s . \\
\frac{P}{E}= & \frac{(1-\alpha-\varphi)\left(1-t_{d}\right)}{\delta+\pi-\left(\alpha r+\varphi \frac{E}{P}+\pi\right)\left(1-t_{c}\right)} \\
= & \frac{(1-(\gamma / r)-\varphi)\left(1-t_{d}\right)}{\delta-\gamma+(\gamma+\pi) t_{c}-\varphi \frac{E}{P}\left(1-t_{c}\right)} \\
= & \frac{1}{r} \cdot \frac{(r-\gamma)\left(1-t_{d}\right)+r \varphi\left(t_{d}-t_{c}\right)}{\delta-\gamma+(\gamma+\pi) t_{c}} .
\end{aligned}
$$

This expression for the price-earnings ratio is identical to the previous expression, except for the additional term in the numerator that represents the reduction in the tax burden that results from shifting dividends to capital gains. This modification also reduces the hurdle rate for marginal investments in capital assets, a rate that falls as a result of this shift in dividend strategy when the tax rate on dividends exceeds the effective tax rate on capital gains

$$
\begin{gathered}
r \geq r_{\min }=\frac{\delta+\pi t_{c}-\gamma\left(t_{d}-t_{c}\right)}{\left(1-t_{d}\right)+\varphi\left(t_{d}-t_{c}\right)} \\
r-\delta \geq \frac{\delta\left(t_{d}+\varphi\left(t_{d}-t_{c}\right)\right)+\pi t_{c}-\gamma\left(t_{d}-t_{c}\right)-r \varphi\left(t_{d}-t_{c}\right)}{\left(1-t_{d}\right)+\varphi\left(t_{d}-t_{c}\right)} .
\end{gathered}
$$

If the company omits the dividend entirely and distributes earnings to shareholders by purchasing its stock only, the minimum rate of return required of marginal investments in capital assets approaches:

$$
\begin{aligned}
r & \geq r_{\min }=\frac{\delta+\pi t_{c}}{1-t_{c}} \\
r-\delta & \geq \frac{(\delta+\pi) t_{c}}{1-t_{c}} .
\end{aligned}
$$

\section{The Effect of Taxes on the Cost of Equity}

When companies distribute earnings to shareholders as dividends, the cost of equity depends on the dividend tax rate. As share purchases displace dividends, the capital gains tax 
supplants the dividend tax. In the expression above, the cost of equity depends on the capital gains tax rate alone because companies distribute their earnings through share purchases only.

This conclusion differs from that of the "new" view of corporate finance in which the company does not necessarily choose its return on capital assets to maximize its value (for example, see Auerbach 2002). Following Auerbach ((2.12) p. 1258), when a company pays dividends and neither issues nor purchases shares, the value of its equity might be expressed as

$$
\begin{aligned}
P_{0} & =\int_{0}^{\infty} \exp \left(-\frac{\delta}{1-t_{c}} s\right)\left(\frac{1-t_{d}}{1-t_{c}}\right)(1-\alpha)\left(r \cdot C_{0}\right) \exp (\gamma s) d s \\
& =\left(\frac{1-t_{d}}{1-t_{c}}\right)(r-\gamma) C_{0} \cdot\left(\frac{1}{\delta /\left(1-t_{c}\right)-\gamma}\right)
\end{aligned}
$$

this appears to imply that the appropriate discount rate is not affected by the dividend tax rate. Only the capital gains tax rate appears with shareholders' required rate of return in this expression. In equilibrium, the market value of companies' new investments in capital assets should be at least as great as the book value of these investments $\left(\frac{P}{C} \geq 1\right)$ :

$$
\begin{aligned}
& 1 \leq\left(\frac{1-t_{d}}{1-t_{c}}\right)\left(\frac{r-\gamma}{\delta /\left(1-t_{c}\right)-\gamma}\right) \Rightarrow \\
& r \geq \frac{\delta-\gamma\left(t_{d}-t_{c}\right)}{\left(1-t_{d}\right)} .
\end{aligned}
$$

This expression, which matches that derived above when companies purchase no shares, shows that the hurdle rate for capital assets depends on the dividend tax rate. The return on capital assets is essentially taxed at the dividend tax rate with the capital gains tax supplanting the dividend tax on retained earnings as companies either retain earnings for growth or, as shown before, for purchasing shares.

\section{The Effect of Taxes on the Cost of Capital}


For a given required return on equity, $\delta$, a fixed rate of share purchases, $\varphi$, and a fixed ratio of debt financing to assets, $\lambda$, a reduction in the tax rate on dividends by amount $\Delta t_{d}$ will reduce the minimum net return that corporations require on new equity capital:

$$
\Delta r_{\min } \approx\left[\frac{-\gamma+(1-\varphi) r_{\min }}{\left(1-t_{d}\right)+\varphi\left(t_{d}-t_{c}\right)}\right] \Delta t_{d}+\left[\frac{\gamma+\pi+\varphi r_{\min }}{\left(1-t_{d}\right)+\varphi\left(t_{d}-t_{c}\right)}\right] \Delta t_{c} .
$$

For companies that pay dividends $((1-\varphi)>\gamma / r)$, the factor in the first set of square brackets is positive.

A tax cut on dividends and capital gains reduces the return corporations require on new capital assets. The net return on capital is the return on assets, $r_{a}$, less interest expense and corporate income taxes, at effective rate $\tau$ (which includes the effects of corporate income tax rates, rules for depreciation allowances, partial expensing, and any tax credits), ${ }^{29}$

$$
\begin{aligned}
& r=\left(r_{a}-\lambda r_{d e b t}\right) \frac{(1-\tau)}{(1-\lambda)} \\
& r_{a}=(1-\lambda) \cdot \frac{r}{(1-\tau)}+\lambda \cdot r_{d e b t} .
\end{aligned}
$$

With perfect competition, constant returns, constant leverage, and no friction

$$
\Delta r_{a} \approx \frac{(1-\lambda)}{(1-\tau)} \Delta r
$$

The lower cost of equity capital resulting from the tax cut could encourage companies to reduce their leverage. A lower degree of leverage, which would tend to reduce lenders' risk premiums, could reduce the cost of debt financing. ${ }^{30}$ Lower leverage also would tend to reduce the risk premium required by shareholders, and this would reduce the cost of equity capital somewhat more.

The CES Production Function, Demand for Capital Assets, the Cost of Capital, and Potential Growth

\footnotetext{
${ }^{29}$ See, for example, Hall and Jorgenson (1967).

${ }^{30}$ To the extent the lower cost of capital encourages companies to expand, as discussed below, lower leverage might not entail a lower demand for debt financing.
} 
The economy-wide consequences of a change in dividend taxes and the cost of capital depend on the response in the demand for capital assets. Using the familiar constant-elasticityof-substitution production function, the services of capital assets $(K)$ and labor $(L)$ combine with their specific technology factors $(T)$ to produce a quantity of output:

$$
\begin{aligned}
Q & =\left[\mu\left(T^{K} K\right)^{\frac{\sigma-1}{\sigma}}+(1-\mu)\left(T^{L} L\right)^{\frac{\sigma-1}{\sigma}}\right]^{\frac{\sigma}{\sigma-1}} \\
& =\left(T^{L} L\right)\left[\mu\left(k^{*}\right)^{\frac{\sigma-1}{\sigma}}+(1-\mu)\right]^{\frac{\sigma}{\sigma-1}} \\
k^{*} & =\frac{T^{K} K}{T^{L} L} .
\end{aligned}
$$

As the elasticity of substitution between capital and labor $(\sigma)$ approaches one, this CES function approaches the Cobb-Douglas form.

Because this function features constant returns to scale, the average returns to factors equal their marginal returns, and if factors' rates of payment equal their returns, the total payment to factors equals output. In competitive markets, when the cost of labor is $w$ and the cost of capital is $r_{a}$, companies maximize their profits when the marginal return to capital goods less economic depreciation at rate dep equals the required return on capital goods, ${ }^{31}$

$$
\begin{aligned}
r_{a} & =\frac{d\left(p_{Q} Q\right)}{d\left(p_{K} K\right)}-d e p \\
& =T^{K}\left(\frac{p_{Q}}{p_{K}}\right) \cdot \mu\left[\mu+(1-\mu)\left(k^{*}\right)^{\frac{1-\sigma}{\sigma}}\right]^{\frac{\sigma}{\sigma-1}}-\text { dep. }
\end{aligned}
$$

The price of new capital goods is not necessarily equal to the price of final output, so the marginal profit of a unit of capital reflects the relative price of capital goods.

In steady-state equilibrium the cost of capital, $r_{a}$, is constant; this condition requires the rate of growth of the effective capital-labor ratio, $k^{*}$, to offset the difference between the rates of

\footnotetext{
31 The net rate of economic depreciation includes obsolescence as well as the change in the relative market and option values of capital. The following expressions, therefore, imply that the marginal product of capital equals the user cost of capital, which reflects the cost of financing, corporate taxation, and changes in the economic value of capital (Hall and Jorgenson 1967).
} 
growth of the technology factor for capital and the relative price of capital goods. If the relative price of capital goods increases at the same rate as companies' technology factor - that is, if the rising price of capital offsets its rising productivity - then the effective capital-labor ratio is constant in the steady state. If the relative price of capital goods is constant, then the effective capital-labor ratio increases at a rate sufficient to offset the rate of growth of capital's technology factor-the rising productivity of capital induces producers to use more capital relative to labor. The potential rate of growth of output, capital assets, and earnings is defined by the rates of growth of the technology factors $\left(\gamma^{K}, \gamma^{L}\right)$, of the labor force $(n)$, and of the relative price of capital goods $(\kappa)$.

When the cost of capital changes, the elasticity of substitution between capital and labor $(\sigma)$ dictates how much the employment of capital assets and the total return to capital will change, other things being equal:

$$
\begin{gathered}
\frac{\Delta K}{K} \approx-\sigma \cdot \frac{\Delta r_{a}}{r_{a}+d e p} \\
\frac{\Delta\left(K \cdot r_{a}\right)}{K \cdot r_{a}} \approx\left[1-\sigma\left(\frac{r_{a}}{r_{a}+d e p}\right)\right] \cdot \frac{\Delta r_{a}}{r_{a}} .
\end{gathered}
$$

When the elasticity is one, a one-percent drop in the cost of capital plus depreciation increases the demand for capital goods by one percent. Because the return on capital assets must cover both the cost of capital and depreciation, a one-percent drop in the cost of capital alone increases the demand for capital goods by less than one percent unless the elasticity of substitution is sufficiently greater than one. If the elasticity is not sufficiently greater than one, the product of $r_{a}$ and the quantity of capital falls in response to a reduction in the cost of capital.

\section{The Cobb-Douglas Production Function: Earnings, Dividends, and Stock Prices}

As the elasticity of substitution approaches one, the production function becomes CobbDouglas, and the distinct technology factors combine into a factor representing total factor productivity. Suppose, further, that capital goods are indistinguishable from other output. 


$$
\begin{aligned}
& Q=T \cdot K^{\beta} L^{1-\beta} \\
& r_{a}=\beta\left(\frac{Q}{K}\right)-\text { dep. }
\end{aligned}
$$

In this case, the return to capital assets is constant when the rate of growth of capital assets equals the rate of growth of output

$$
\gamma=n+\gamma^{T} /(1-\beta)
$$

If the rate of growth of the labor force (adjusted for quality) is 1.3 percent, total factor productivity grows by 1.1 percent, and $\beta$ equals 0.3 , the potential rate of growth of output is 3.5 percent. Potential growth can exceed 3.5 percent if capital goods are distinct from other goods and if technological progress allows the output of these goods to grow more rapidly than the output of other goods.

With perfect competition, constant returns, constant leverage, and no friction, the previous expressions combine to describe the effects of a cut in the dividend tax rate on the rates of return on equity and capital assets, on the demand for capital assets, and on the priceearnings ratio:

$$
\begin{aligned}
& \frac{\Delta r}{r} \approx\left[\frac{1-(\gamma / r)-\varphi}{\left(1-t_{d}\right)+\varphi\left(t_{d}-t_{c}\right)}\right] \Delta t_{d}+\left[\frac{\varphi+(\gamma+\pi) / r}{\left(1-t_{d}\right)+\varphi\left(t_{d}-t_{c}\right)}\right] \Delta t_{c} \\
& \frac{\Delta r_{a}}{r_{a}} \approx\left(\frac{r}{r_{a}} \cdot \frac{1-\lambda}{1-\tau}\right) \cdot \frac{\Delta r}{r} \\
& \frac{\Delta K}{K} \approx-\left(\frac{r_{a}}{r_{a}+d e p}\right) \cdot \frac{\Delta r_{a}}{r_{a}} \\
& \frac{\Delta\left(\frac{P}{E}\right)}{\left(\frac{P}{E}\right)} \approx-\left[\frac{\gamma / r}{\delta-\gamma+(\gamma+\pi) t_{c}}\right] \cdot \frac{\Delta r}{r}-\left[\frac{1-(\gamma / r)-\varphi}{\delta-\gamma+(\gamma+\pi) t_{c}}\right] \Delta t_{d}-\left[\frac{\varphi+r(\gamma+\pi)}{\delta-\gamma+(\gamma+\pi) t_{c}}\right] \Delta t_{c} .
\end{aligned}
$$

When companies distribute their earnings by purchasing shares instead of paying dividends, the numerator of the first term in the first expression and of the second term in the last expression are zero; otherwise, all the factors in the square brackets are positive. For typical values of leverage and marginal effective tax rates on corporate income, the percentage drop in 
the cost of equity exceeds that of the cost of capital, and the magnitude of the percentage drop in the cost of capital exceeds the percentage increase in capital assets. The tax cut unambiguously increases the price-earnings ratio.

When the elasticity of substitution is not significantly greater than one and constant returns to scale apply, the dividend tax cut likely reduces aggregate earnings:

$$
\frac{\Delta E}{E}=\frac{\Delta(K(1-\lambda) \cdot r)}{K(1-\lambda) \cdot r} \approx\left[1-\left(\frac{(1-\lambda) \cdot r /(1-\tau)}{r_{a}+\operatorname{dep}}\right)\right] \cdot \frac{\Delta r}{r} .
$$

A drop in the cost of equity increases aggregate earnings only if the cost of equity capital is sufficiently high compared with the cost of debt and the rate of depreciation, given the effective corporate tax rate and the degree of leverage. For example, if the corporate tax rate is 30 percent, leverage is 50 percent, the real cost of debt is 2 percent, and the rate of depreciation is 10 percent, the cost of equity capital must exceed 50 percent for a drop in the cost of equity to increase aggregate earnings.

When companies experience constant returns to scale and are expected to distribute a share of their earnings as dividends, a tax cut on dividends and capital gains reduces the cost of capital and increases the capital-labor ratio. It also reduces the rate of return on equity capital and increases the price-earnings ratio for equity. The greater capital intensity of production increases output per capita and real wages. The tax cut reduces the total earnings accruing to capital assets when the elasticity of substitution between capital and labor is not significantly greater than one. In this case, a likely drop in aggregate earnings is offset by a higher market valuation of earnings, thereby raising the aggregate market value of equity.

The lower required return on assets encourages companies to expand and to employ methods of production that use capital assets more intensively, increasing the economy's rate of growth temporarily as the capital-labor ratio increases to reach its new equilibrium path. Unless the transition to these new techniques and scale of production increases the rate of technological change and the growth of productivity more than temporarily, the tax cut will not alter companies' longer-run growth. 


\section{References}

Allen, Franklin and Roni Michaely. 2002. “Payout Policy.” University of Pennsylvania, photocopy, April.

Antras, Pol. 2004. "Is the U.S. Aggregate Production Function Cobb-Douglas? New Estimates of the Elasticity of Substitution." Contributions to Macroeconomics, 4(1), pp. 1-34.

Arnott, Robert D. and Clifford S. Asness. 2003. "Surprise! Higher Dividends = Higher Earnings Growth." Financial Analysts Journal, January/February, pp. 70-87.

Auerbach, Alan. 2002. “Taxation and Corporate Financial Policy.” Alan Auerbach and Martin Feldstein, eds., Handbook of Public Economics, vol. 3. Amsterdam: North-Holland, pp. 1251-92.

Black, Fisher. 1976. “The Dividend Puzzle.” Journal of Portfolio Management, 2(2), pp. 5-8.

Blouin, Jennifer, Jana Smith Raedy, and Douglas A. Shackelford. 2004. “Did Dividends Increase Immediately After the 2003 Reduction in Tax Rates?" National Bureau of Economic Research, Working Paper 10301, February.

Brav, Alon, John R. Graham, Campbell R. Harvey, and Roni Michaely. 2003. "Payout Policy in the $21^{\text {st }}$ Century." National Bureau of Economic Research, Working Paper 9657, April.

Carroll, Robert, Kevin A. Hassett, and James B. Mackie, III. 2003. “The Effect of Dividend Tax Relief on Investment Incentives.” National Tax Journal, 56(3), September, pp. 629-651.

Chetty, Raj and Emmanuel Saez. 2004. “Do Dividend Payments Respond to Taxes? Preliminary Evidence from the 2003 Dividend Tax Cut." National Bureau of Economic Research, Working Paper 10572, June.

DeAngelo, Harry and Linda DeAngelo. 2004. "Payout Policy Irrelevance and the Dividend Puzzle." Marshall School of Business, University of Southern California, photocopy, March.

DeAngelo, Harry, Linda DeAngelo, and Douglas J. Skinner. 2004. “Are Dividends Disappearing? Dividend Concentration and the Consolidation of Earnings." Journal of Financial Economics, 72(3), June, pp. 425-456.

DeAngelo, Harry, Linda DeAngelo, and Rene M. Stulz. 2004. “Dividend Policy, Agency Costs, and Earned Equity." National Bureau of Economic Research, Working Paper 10599, June. 
Dittmar, Amy K. and Robert F. Dittmar. 2002. "Stock Repurchase Waves: An Explanation of the Trends in Aggregate Corporate Payout Policy." Indiana University, photocopy, October 30.

Fama, Eugene F. and Kenneth R. French. 2001. “Disappearing Dividends: Changing Firm Characteristics or Lower Propensity to Pay?" Journal of Financial Economics, 60(1), April, pp. 3-43.

Gravelle, Jane. 2003. "Effects of Dividend Relief on Economic Growth, the Stock Market, and Corporate Tax Preferences." National Tax Journal, 56(3), September, pp. 653-72.

Grullon, Gustavo and Roni Michaely. 2002. “Dividends, Share Repurchases, and the Substitution Hypothesis. Journal of Finance, 57(4), August, pp. 1649-84.

Hall, Robert. E. and Dale. W. Jorgenson. 1967. "Tax Policy and Investment Behavior." American Economic Review, 57(3), June, pp. 391-414.

Koch, Adam S. and Amy X. Sun. 2004. “Dividend Changes and the Persistence of Past Earnings Changes." Journal of Finance, 59(5), October, pp. 2093-2116.

Kopcke, Richard W. and Matthew S. Rutledge. 2004. "Stock Prices and the Equity Premium during the Recent Bull and Bear Markets." New England Economic Review, first quarter, pp. 63-85.

Lintner, John. 1956. “Distribution of Incomes of Corporations Among Dividends, Retained Earnings, and Taxes." American Economic Review, 46(2), pp. 97-113.

Mankiw, N. Gregory and Matthew Weinzierl. 2004. “Dynamic Scoring: A Back-of-the-Envelope Guide." National Bureau of Economic Research, Working Paper w11000, December.

Miller, Merton. 1977. “Debt and Taxes.” Journal of Finance, 32(2), May, pp. 261-75.

Miller, Merton and Franco Modigliani. 1961. “Dividend Policy, Growth, and the Valuation of Shares." Journal of Business, 34(4), pp. 411-33.

Poterba, James. 2004. “Taxation and Corporate Payout Policy.” American Economic Review, 94(2), May, pp.171-175.

Shefrin, Hersh M. and Meir Statman. 1984. “Explaining Investor Preference for Cash Dividends." Journal of Financial Economics, 13(2), June, pp. 253-82.

Standard \& Poor's. 2004. “The Outlook." December 8, p 1. 
Table 1

Composition of the Real Return on Common Stock of the S\&P 500 (Annual Averages)

\begin{tabular}{lccccc} 
& Real Return & Dividend Yield & $\begin{array}{c}\text { Real } \\
\text { Appreciation }\end{array}$ & $\begin{array}{c}\text { Nominal } \\
\text { Appreciation }\end{array}$ & $\begin{array}{c}\text { Price-Earnings } \\
\text { Ratio }\end{array}$ \\
\hline 1947 - present & $7.6 \%$ & $3.7 \%$ & $3.7 \%$ & $7.7 \%$ & 16.3 \\
1947 - 1994 & $7.6 \%$ & $4.1 \%$ & $3.2 \%$ & $7.5 \%$ & 14.0 \\
1995 -present & $8.4 \%$ & $1.7 \%$ & $6.6 \%$ & $9.3 \%$ & 27.3 \\
\hline
\end{tabular}

Growth of Output and Earnings (Annual Averages)

\begin{tabular}{lccccc}
\hline & & \multicolumn{5}{c}{$\begin{array}{c}\text { S\&P } 500 \\
\text { Nominal } \\
\text { Earnings per } \\
\text { share }\end{array}$} & $\begin{array}{c}\text { S\&P } 500 \\
\text { Real Earnings } \\
\text { per share }\end{array}$ & Payout Ratio \\
\hline 1948 - present & $7.0 \%$ & $3.4 \%$ & $6.5 \%$ & $2.9 \%$ & $49.8 \%$ \\
1948 - 1994 & $7.4 \%$ & $3.5 \%$ & $7.4 \%$ & $3.2 \%$ & $51.6 \%$ \\
1995 - present & $5.2 \%$ & $3.3 \%$ & $6.6 \%$ & $4.7 \%$ & $41.4 \%$ \\
\hline
\end{tabular}

Source: Ibbotson Associates, Bureau of Economic Analysis, Standard and Poor's, Haver Analytics 
Table 2

Assets, Earnings, and Dividends of 605 S\&P 500 Companies by Share Purchase Policy,1985 and 2003

\begin{tabular}{|c|c|c|c|c|c|c|c|}
\hline \multirow{6}{*}{$\begin{array}{l}\text { No Reduction in Shares } \\
\text { Some Share Purchases } \\
\text { Favor Share Purchases } \\
\text { Strongly Favor Share Purchases }\end{array}$} & \multirow{3}{*}{\begin{tabular}{|c|}
$\begin{array}{c}\text { Number of } \\
\text { Corporations }\end{array}$ \\
464 \\
\end{tabular}} & \multicolumn{2}{|c|}{$\begin{array}{l}\text { Total Assets } \\
\text { (billions of \$) }\end{array}$} & \multicolumn{2}{|c|}{$\begin{array}{l}\text { Total Earnings } \\
\text { (billions of \$) }\end{array}$} & \multicolumn{2}{|c|}{$\begin{array}{c}\text { Total Dividends } \\
\text { (billions of \$) }\end{array}$} \\
\hline & & 1985 & 2003 & 1985 & 2003 & 1985 & 2003 \\
\hline & & 1831.9 & 16283.5 & 54.7 & 364.9 & 27.9 & 96.7 \\
\hline & 113 & 713.6 & 4808.3 & 29.6 & 132.5 & 12.7 & 55.3 \\
\hline & 15 & 151.4 & 559.4 & 6.9 & 14.3 & 3.4 & 2.2 \\
\hline & 13 & 10.5 & 114.6 & 0.6 & 8.8 & 0.2 & 0.2 \\
\hline & \multicolumn{7}{|c|}{$\%$ of Total } \\
\hline No Reduction in Shares & 76.7 & 67.7 & 74.8 & 59.6 & 70.1 & 63.1 & 62.7 \\
\hline Some Share Purchases & 18.7 & 26.4 & 22.1 & 32.2 & 25.5 & 28.6 & 35.8 \\
\hline Favor Share Purchases & 2.5 & 5.6 & 2.6 & 7.6 & 2.8 & 7.8 & 1.4 \\
\hline Strongly Favor Share Purchases & 2.1 & 0.4 & 0.5 & 0.6 & 1.7 & 0.5 & 0.1 \\
\hline
\end{tabular}

\begin{tabular}{|l|cc|cc|}
\hline \multirow{4}{*}{ No Reduction in Shares } & \multicolumn{2}{|c|}{$\begin{array}{c}\text { Total Dividends to } \\
\text { Total Earnings* }\end{array}$} & \multicolumn{2}{c|}{$\begin{array}{c}\text { Dividends to Earnings } \\
\text { Weighted by M.Cap. }\end{array}$} \\
\cline { 2 - 5 } Some Share Purchases & 1985 & 2003 & 1985 & 2003 \\
\cline { 2 - 5 } Favor Share Purchases & 47.3 & 23.7 & 71.7 & 33.5 \\
Strongly Favor Share Purchases & 42.8 & 41.5 & 48.3 & 42.3 \\
& 43.2 & 14.6 & 38.7 & 13.8 \\
\hline
\end{tabular}

*Only companies with positive earnings are included in calculations.

Source: Compustat 
Table 3

\section{Effect of Dividend and Capital Gains Taxes on the Cost of Equity}

Corporations' Required Internal Rate of Return to Provide Shareholders with 5 Percent Real After-Tax Return

\begin{tabular}{|c|c|c|}
\hline & \begin{tabular}{|c} 
Corporation Does Not Grow \\
Corporation Pays Out All Earnings As Dividends
\end{tabular} & $\begin{array}{c}\text { Corporation Grows at 3.5 Percent Real Rate } \\
\text { Corporation Pays Dividends and Retains Earnings }\end{array}$ \\
\hline $\begin{array}{r}\text { Panel a: No Taxes } \\
\text { No Inflation }\end{array}$ & $5.0 \%$ & $5.0 \%$ \\
\hline $\begin{array}{r}\text { Panel b: No Dividend Tax } \\
\text { Capital Gains Tax } 18.9 \% \\
\text { No Inflation }\end{array}$ & $5.0 \%$ & $5.7 \%$ \\
\hline $\begin{array}{r}\text { Panel c: No Dividend Tax } \\
\text { Capital Gains Tax } 18.9 \% \\
\text { Inflation } 2 \%\end{array}$ & $5.0 \%$ & $6.0 \%$ \\
\hline $\begin{array}{r}\text { Panel d: Dividend Tax } 27.8 \% \\
\text { Capital Gains Tax } 18.9 \% \\
\text { Inflation } 2 \%\end{array}$ & $6.9 \%$ & $7.0 \%$ \\
\hline $\begin{array}{r}\text { Panel e: Dividend Tax } 13.7 \% \\
\text { Capital Gains Tax } 14.1 \% \\
\text { Inflation } 2 \%\end{array}$ & $5.7 \%$ & $6.1 \%$ \\
\hline
\end{tabular}

Source: Author's calculations. 
Table 4

Effective Marginal Personal Tax Rates on Dividends and Capital Gains

Before and After the Jobs and Growth Tax Relief Reconciliation Act of 2003

\begin{tabular}{l|cc} 
& Before JGTRRA & After JGTRRA \\
\hline Dividends & $27.8 \%$ & $13.7 \%$ \\
Capital Gains & $18.9 \%$ & $14.1 \%$
\end{tabular}

Source: Congressional Budget Office, unpublished data for the years 2002 and 2003. 


\section{Table 5}

\section{Effect of Tax Cuts on Firms' Cost of Equity and Cost of Capital*}

\section{Cost of Equity}

Shareholders' Required Rate

of Real After-Tax Return

\begin{tabular}{|c|c|c|c|c|c|c|}
\hline \multirow{3}{*}{$\begin{array}{l}\text { Rate of } \\
\text { Potential Growth }\end{array}$} & \multicolumn{2}{|c|}{4 percent } & \multicolumn{2}{|c|}{5 percent } & \multicolumn{2}{|c|}{6 percent } \\
\hline & \multicolumn{2}{|c|}{ Tax Rates: } & \multicolumn{2}{|c|}{ Tax Rates: } & \multicolumn{2}{|c|}{ Tax Rates: } \\
\hline & Before JGTRRA & After JGTRRA & Before JGTRRA & After JGTRRA & Before JGTRRA & After JGTRRA \\
\hline 3.25 percent & $5.69 \%$ & $5.06 \%$ & $7.05 \%$ & $6.22 \%$ & $8.41 \%$ & $7.38 \%$ \\
\hline 4 percent & $5.60 \%$ & $5.07 \%$ & $6.96 \%$ & $6.23 \%$ & $8.32 \%$ & $7.38 \%$ \\
\hline
\end{tabular}

\section{Cost of Capital*}

Shareholders' Required Rate

Of Real After-Tax Return

\begin{tabular}{|c|c|c|c|c|c|c|}
\hline \multirow{3}{*}{$\begin{array}{l}\text { Rate of } \\
\text { Potential Growth }\end{array}$} & \multicolumn{2}{|c|}{4 percent } & \multicolumn{2}{|c|}{5 percent } & \multicolumn{2}{|c|}{6 percent } \\
\hline & \multicolumn{2}{|c|}{ Tax Rates: } & \multicolumn{2}{|c|}{ Tax Rates: } & \multicolumn{2}{|c|}{ Tax Rates: } \\
\hline & Before JGTRRA & After JGTRRA & Before JGTRRA & After JGTRRA & Before JGTRRA & After JGTRRA \\
\hline 3.25 percent & $5.86 \%$ & $5.29 \%$ & $7.11 \%$ & $6.35 \%$ & $8.35 \%$ & $7.41 \%$ \\
\hline 4 percent & $5.78 \%$ & $5.29 \%$ & $7.02 \%$ & $6.35 \%$ & $8.27 \%$ & $7.41 \%$ \\
\hline
\end{tabular}

*As used here, "capital" includes equity plus debt financing.

Source: Author's calculations. 


\section{Table 6}

\section{Effect of Tax Cuts on the Demand for Capital Assets and the Net Return to Equity Capital}

\section{Demand for Capital Assets}

Shareholders' Required Rate

of Real After-Tax Return

4 percent

Change in Demand

for Capital Assets

with JGTRRA

Potential Growth

3.25 percent

4 percent

$3.86 \%$

5 percent

6 percent

Change in Demand Change in Demand

for Capital Assets for Capital Assets

with JGTRRA with JGTRRA

\section{capital}

\section{Net Return to Equity Capital}

Shareholders' Required Rate

Of Real After-Tax Return

\begin{tabular}{c|ccc}
$\begin{array}{c}\text { Rate of } \\
\text { Potential Growth }\end{array}$ & $\begin{array}{c}\text { Change in } \\
\text { Net Income } \\
\text { with JGTRRA }\end{array}$ & $\begin{array}{c}\text { Change in } \\
\text { Net Income } \\
\text { with JGTRRA }\end{array}$ & $\begin{array}{c}\text { Change in } \\
\text { Net Income } \\
\text { with JGTRRA }\end{array}$ \\
\hline 3.25 percent & $-7.16 \%$ & $-7.04 \%$ & $-6.80 \%$ \\
4 percent & $-6.22 \%$ & $-6.35 \%$ & $-6.28 \%$ \\
\hline
\end{tabular}

Source: Author's calculations. 


\section{Table 7}

\section{Effect of Tax Cuts on Price-Earnings Ratios and the Market Value of Equity}

\section{Price-Earnings Ratio}

Shareholders' Required Real Rate of Return

4 percent

5 percent

6 percent

\begin{tabular}{c|ccc}
\hline $\begin{array}{c}\text { Rate of } \\
\text { Potential Growth }\end{array}$ & $\begin{array}{c}\text { Change in } \\
\text { P/E Ratio } \\
\text { with JGTRRA }\end{array}$ & $\begin{array}{c}\text { Change in } \\
\text { P/E Ratio } \\
\text { with JGTRRA }\end{array}$ & $\begin{array}{c}\text { Change in } \\
\text { P/E Ratio } \\
\text { with JGTRRA }\end{array}$ \\
\hline 3.25 percent & $12.38 \%$ & $13.29 \%$ & $13.92 \%$ \\
4 percent & $10.51 \%$ & $11.77 \%$ & $12.64 \%$ \\
\hline
\end{tabular}

\section{Market Value of Equity}

Shareholders' Required Real Rate of Return

\begin{tabular}{c|ccc} 
Real Rate of Return & 4 percent & 5 percent & 6 percent \\
$\begin{array}{c}\text { Rate of } \\
\text { Potential Growth }\end{array}$ & $\begin{array}{c}\text { Change in } \\
\text { Net Income } \\
\text { with JGTRRA }\end{array}$ & $\begin{array}{c}\text { Change in } \\
\text { Net Income } \\
\text { with JGTRRA }\end{array}$ & $\begin{array}{c}\text { Change in } \\
\text { Net Income } \\
\text { with JGTRRA }\end{array}$ \\
\hline 3.25 percent & $5.22 \%$ & $6.25 \%$ & $7.11 \%$ \\
4 percent & $4.29 \%$ & $5.42 \%$ & $6.36 \%$ \\
\hline
\end{tabular}

Source: Author's calculations. 
Chart 1

Earnings and Dividends for the S\&P 500

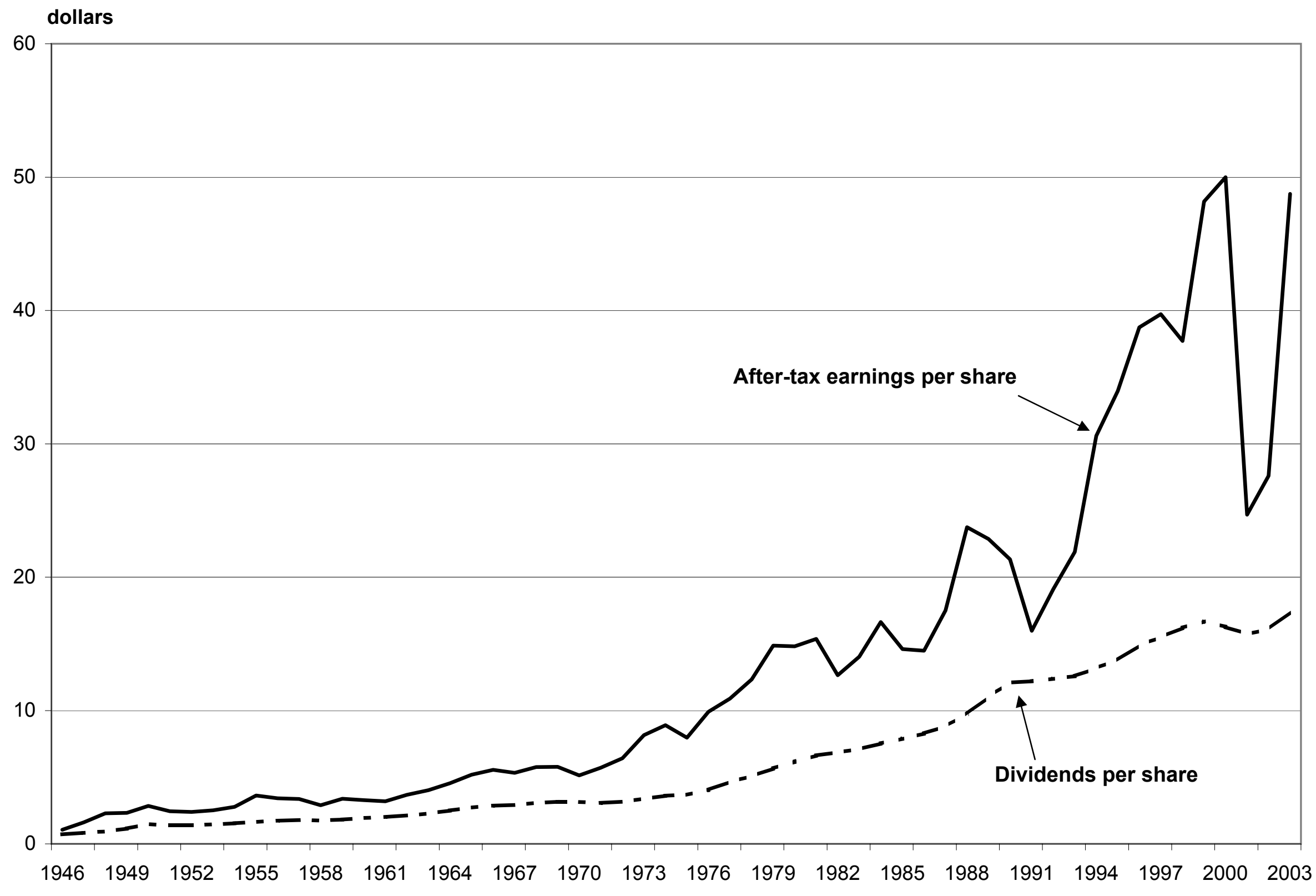

source: Standard \& Poor's data supplied by Haver Analytics, Inc. 


\section{Chart 2 Dividend Payout Ratio}

Percent

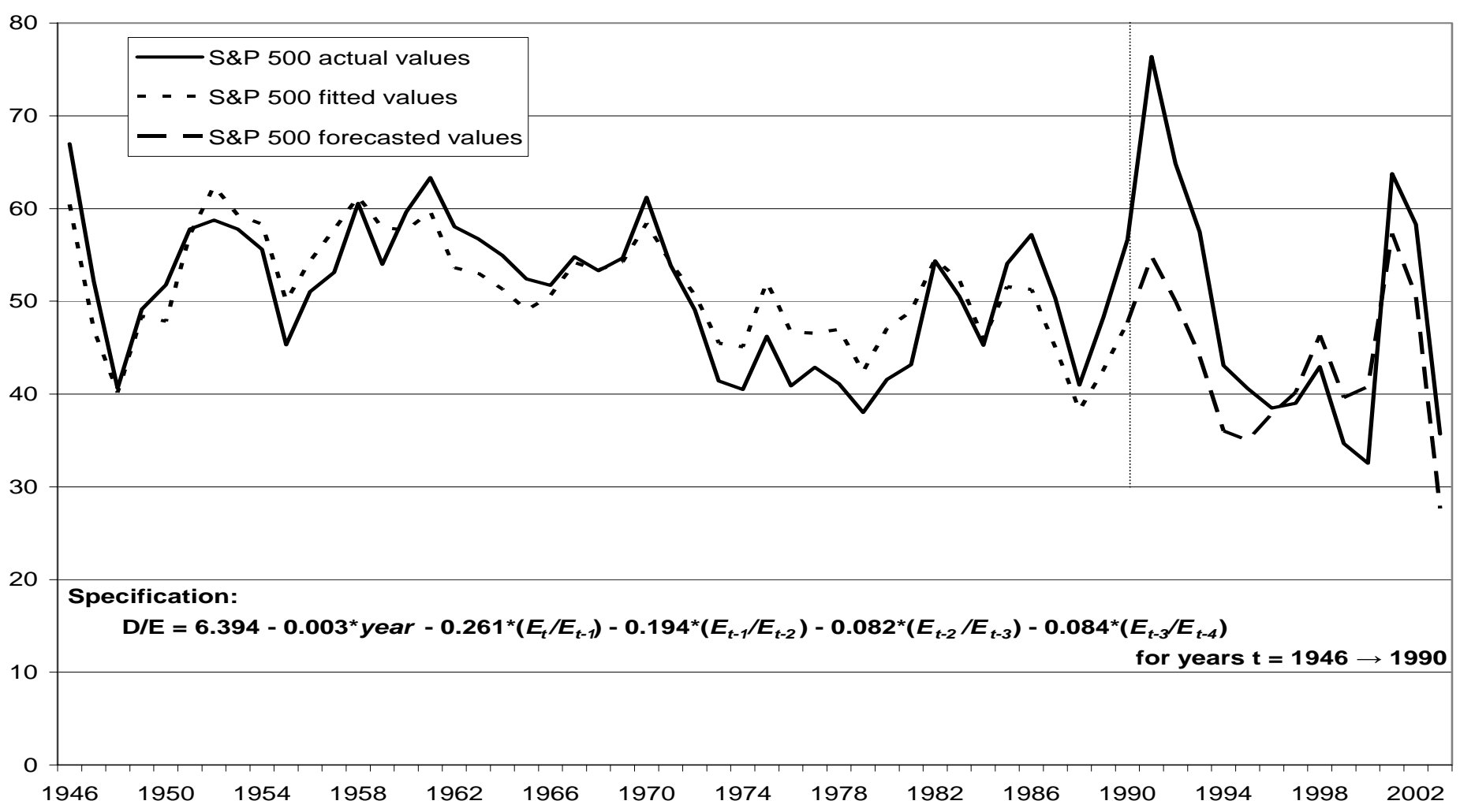

Source: Author's calculations on S\&P 500 data obtained through Haver Analytics.

\section{Percent}

All U.S. Corporations (NIPA data)

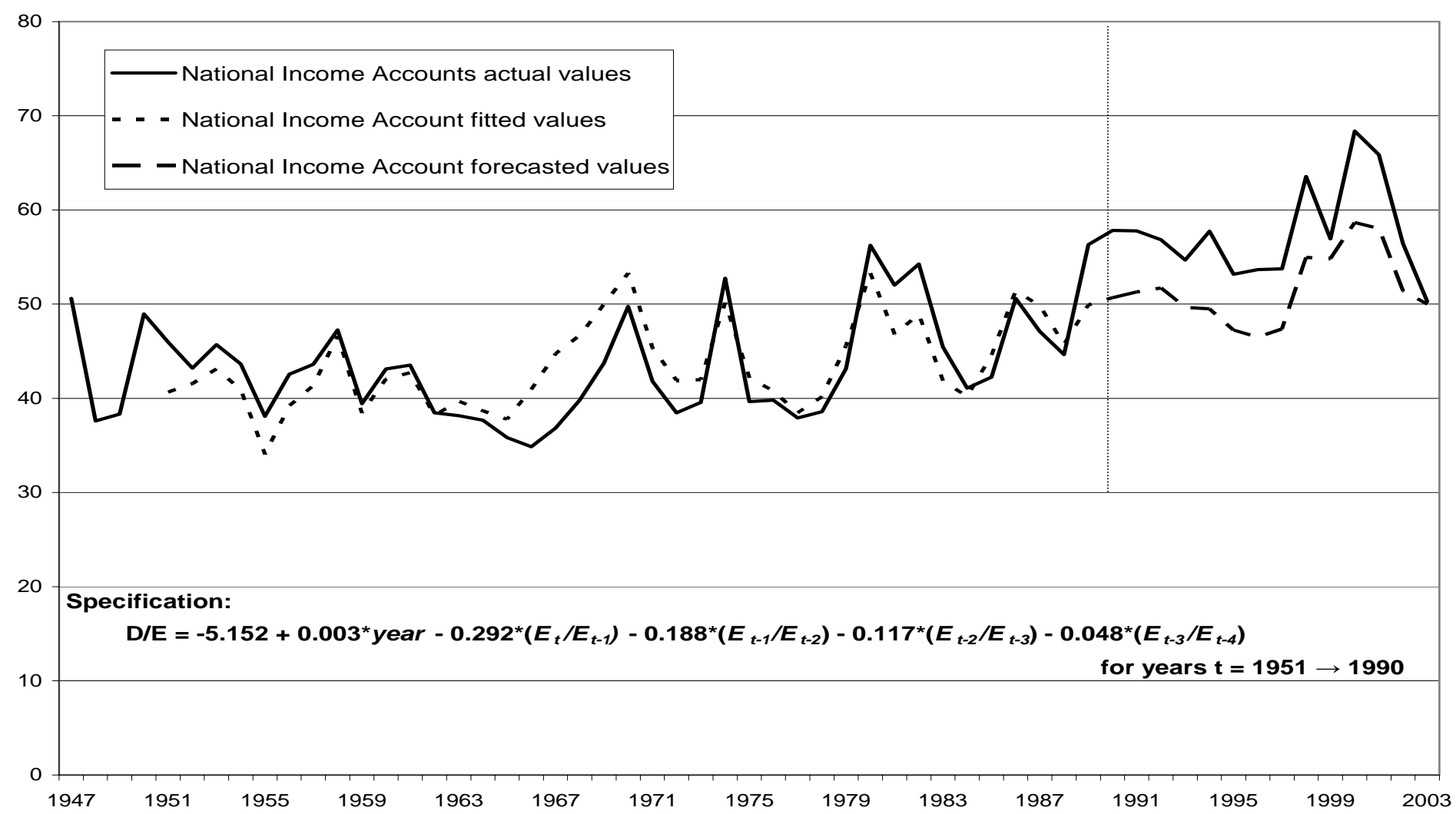

Source: National Income and Product Accounts data on after-tax dividends expressed as a percent of after-tax corporate profits with inventory valuation and capital consumption adjustments. Data obtained from Haver Analytics. 


\section{Chart 3}

\section{Bemis Company}

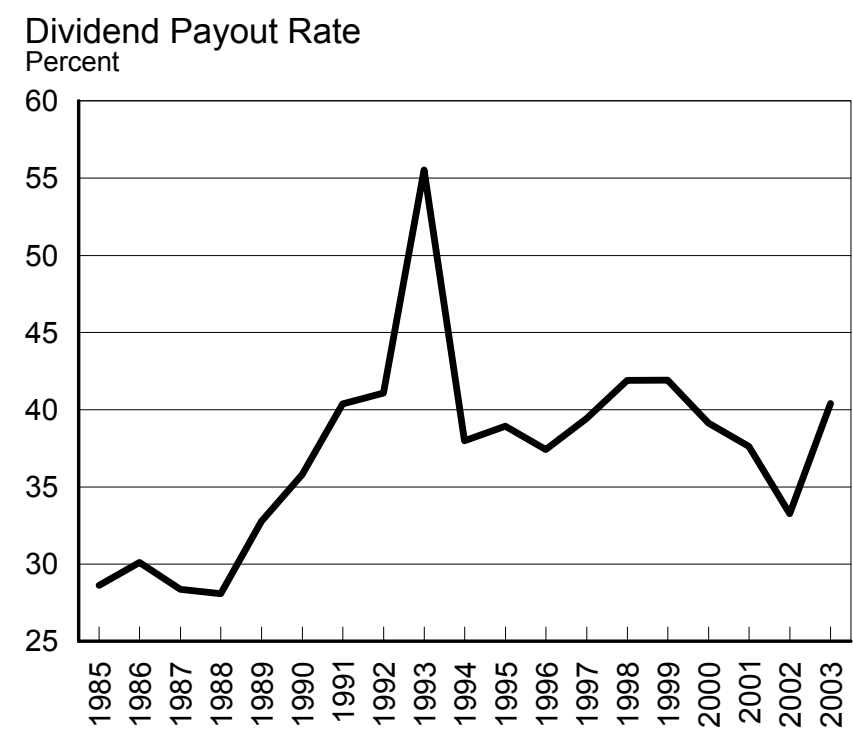

\section{Book Value per Share} Dollars

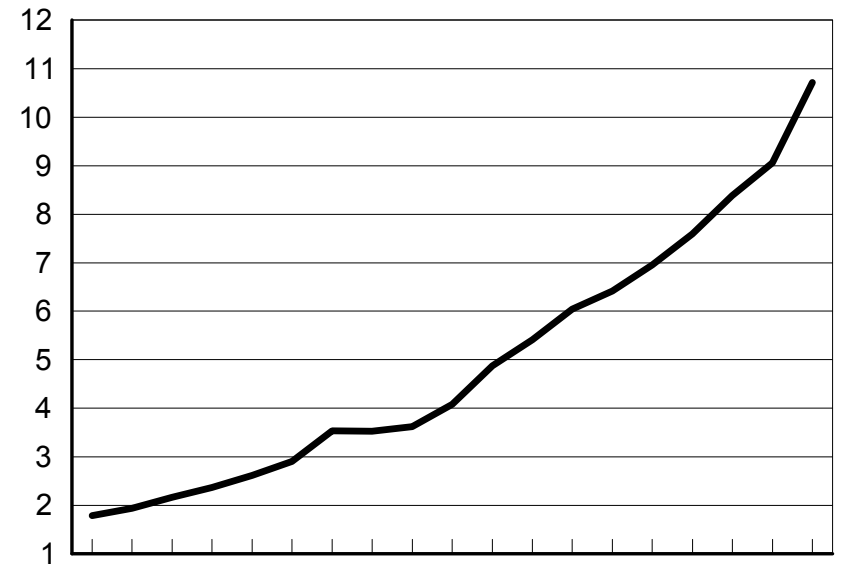

ம

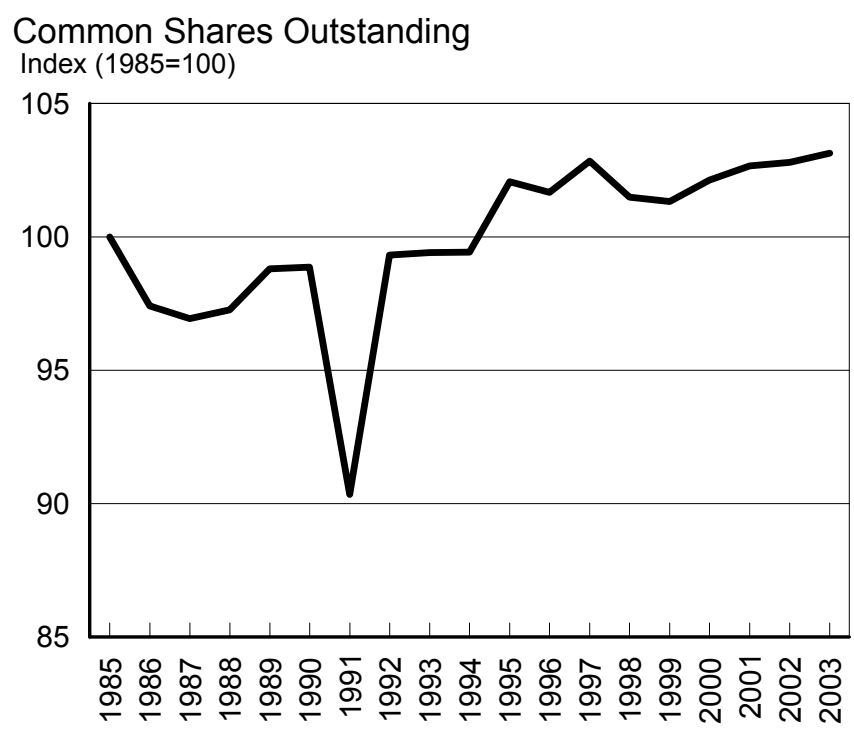

Dividend to Book Capital (solid line)

Net Stock Purchases to Book Capital (dashed line)

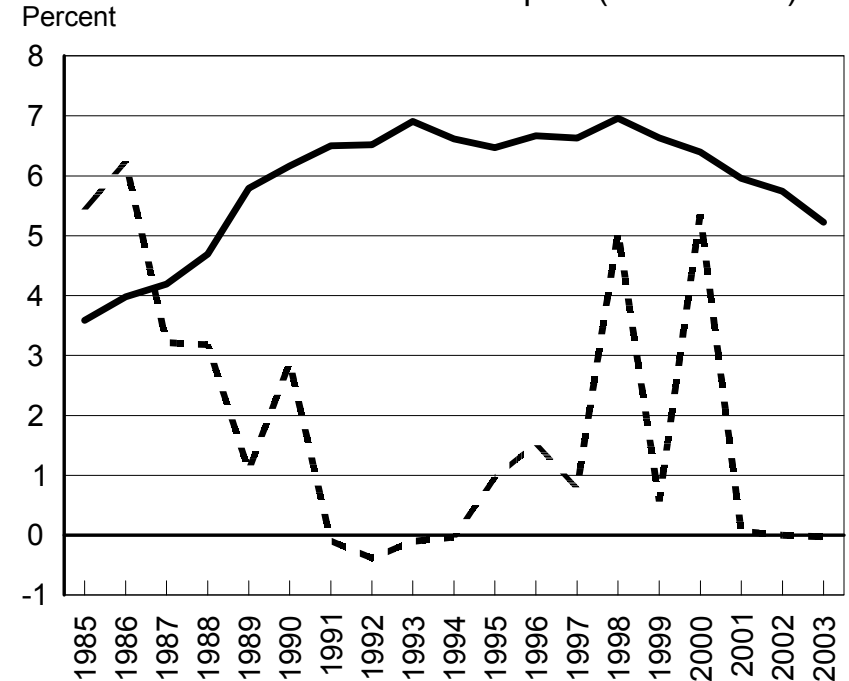

Source: Compustat 


\section{Chart 4}

\section{Johnson \& Johnson Company}

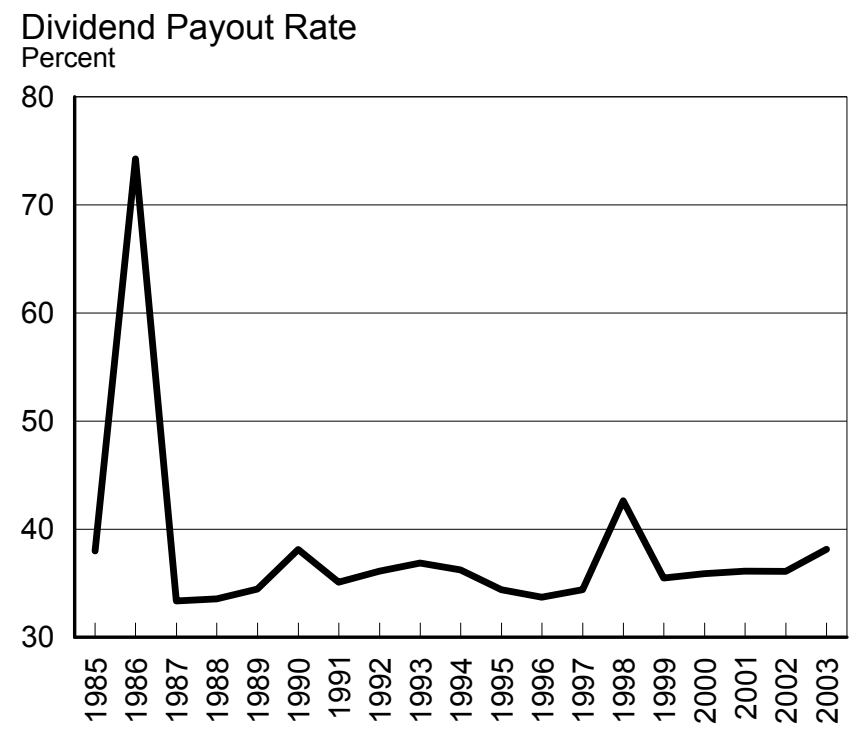

\section{Book Value per Share} Dollars

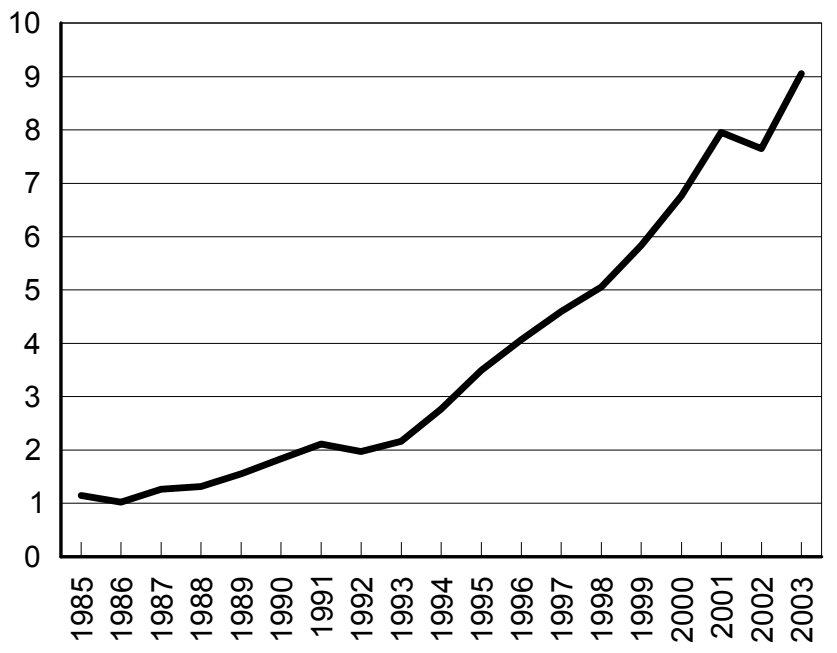

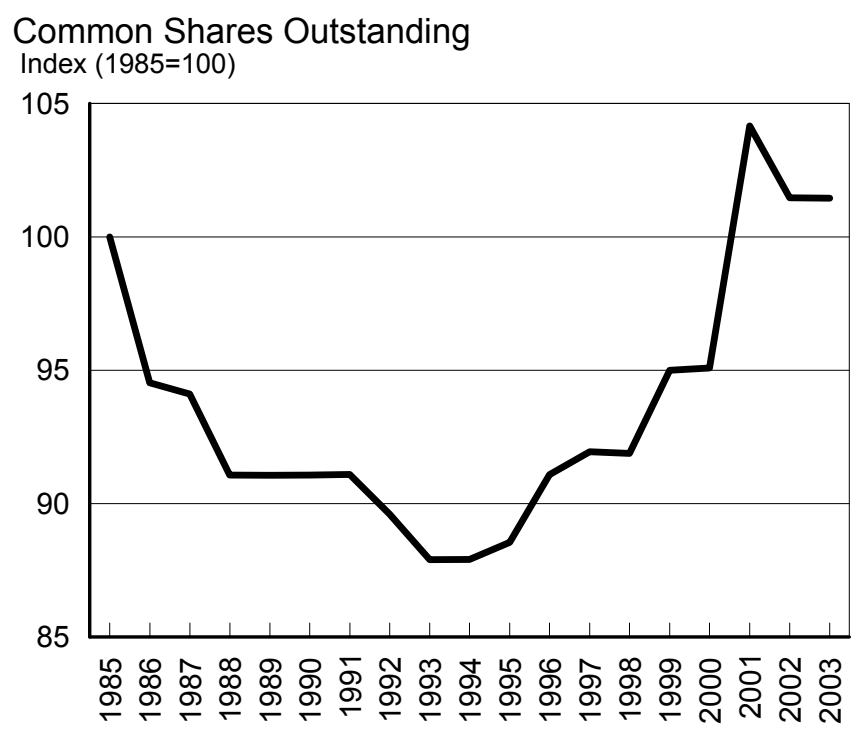

Dividend to Book Capital (solid line)

Net Stock Purchases to Book Capital (dashed line) rercent

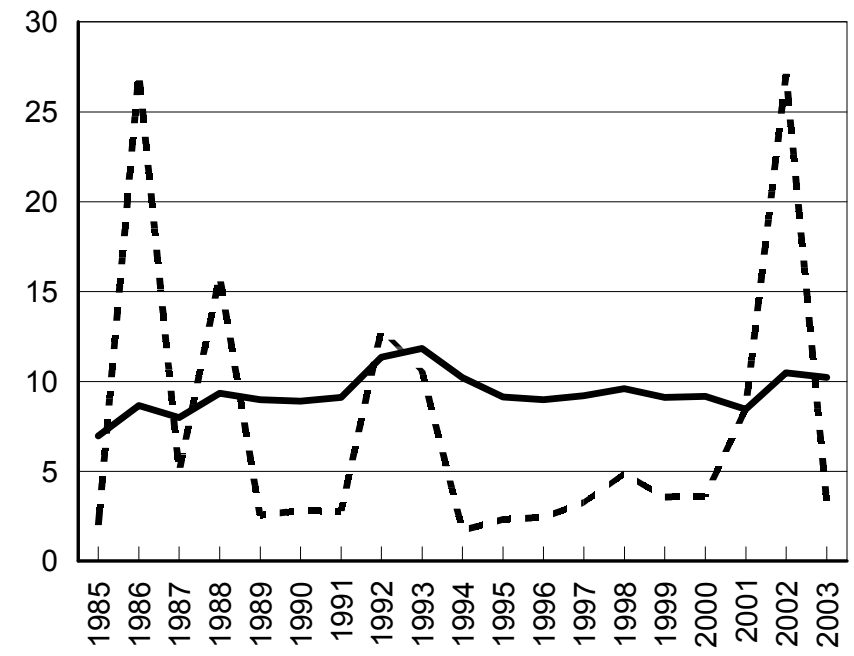

Source: Compustat 


\section{Chart 5}

\section{M Company}

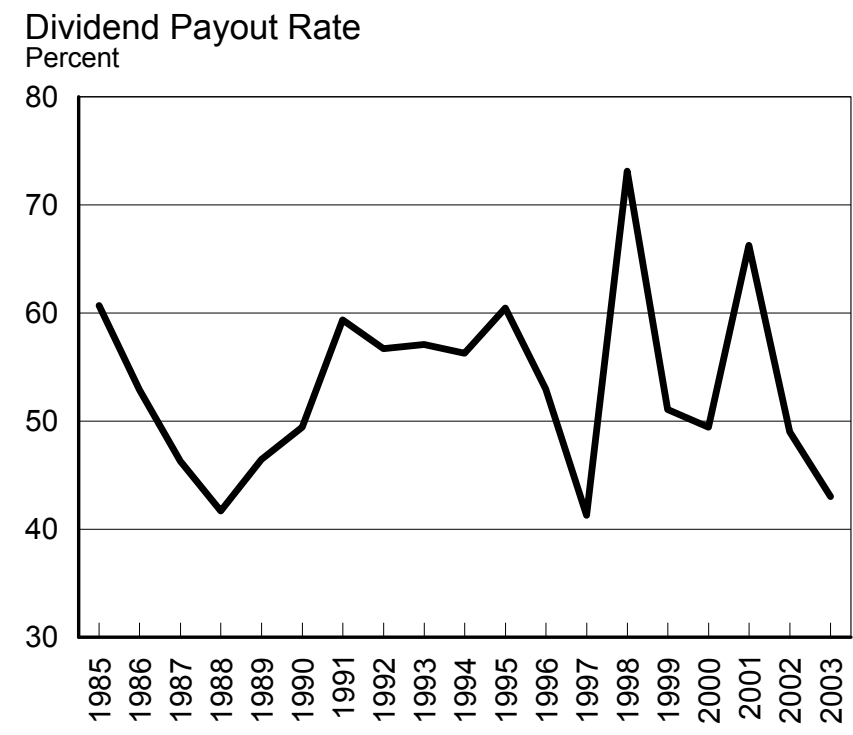

\section{Book Value per Share} Dollars

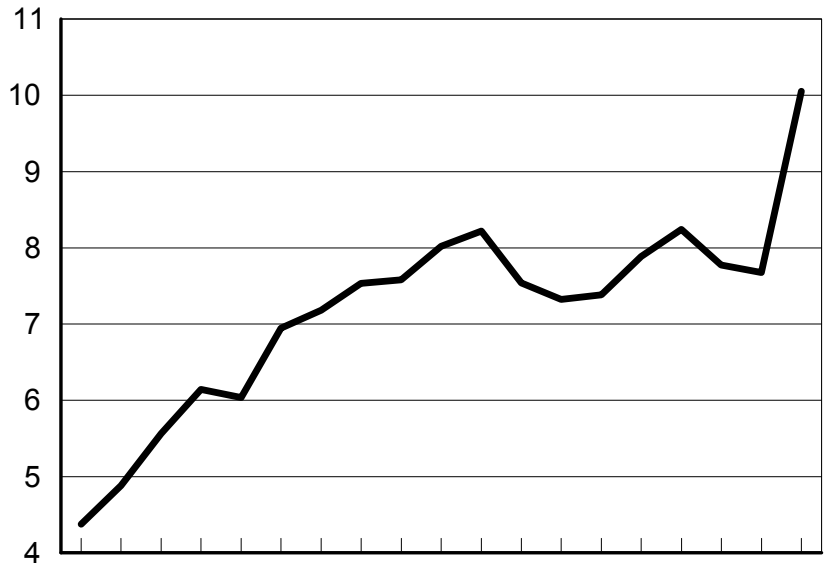

ம

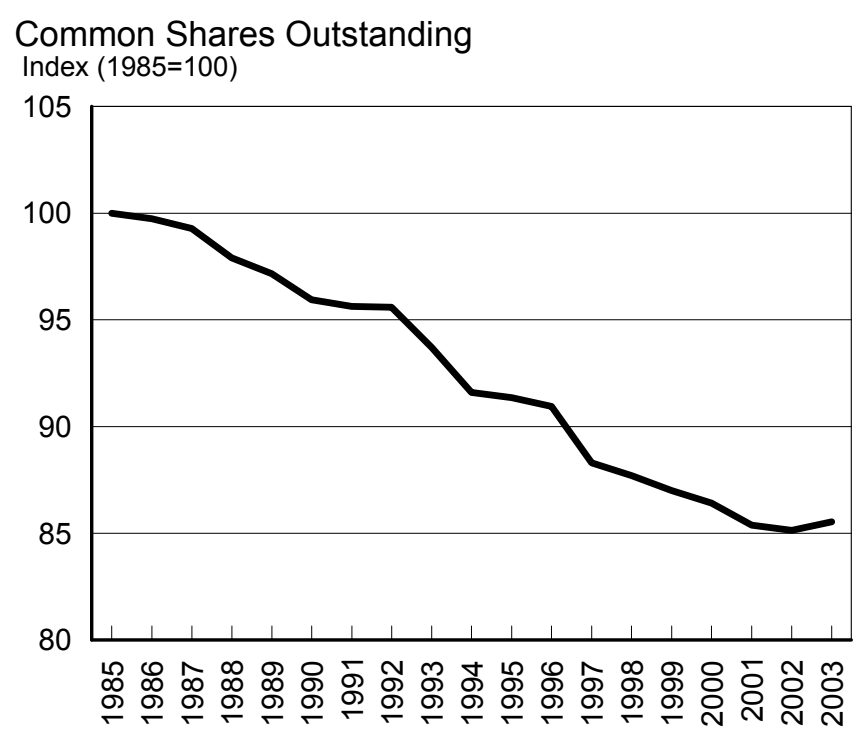

Dividend to Book Capital (solid line)

Net Stock Purchases to Book Capital (dashed line) Percent

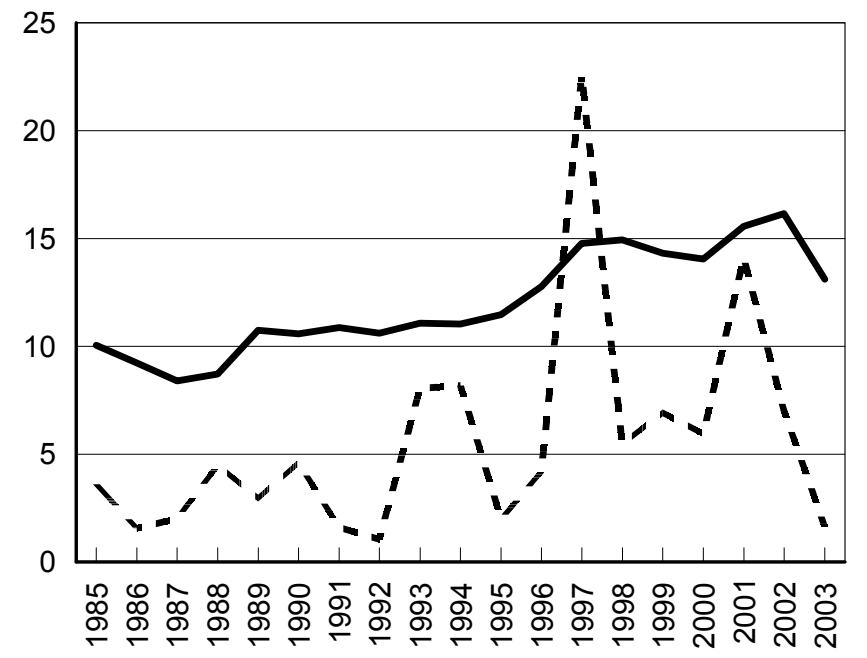

Source: Compustat 


\section{Chart 6}

\section{Coca-Cola Company}

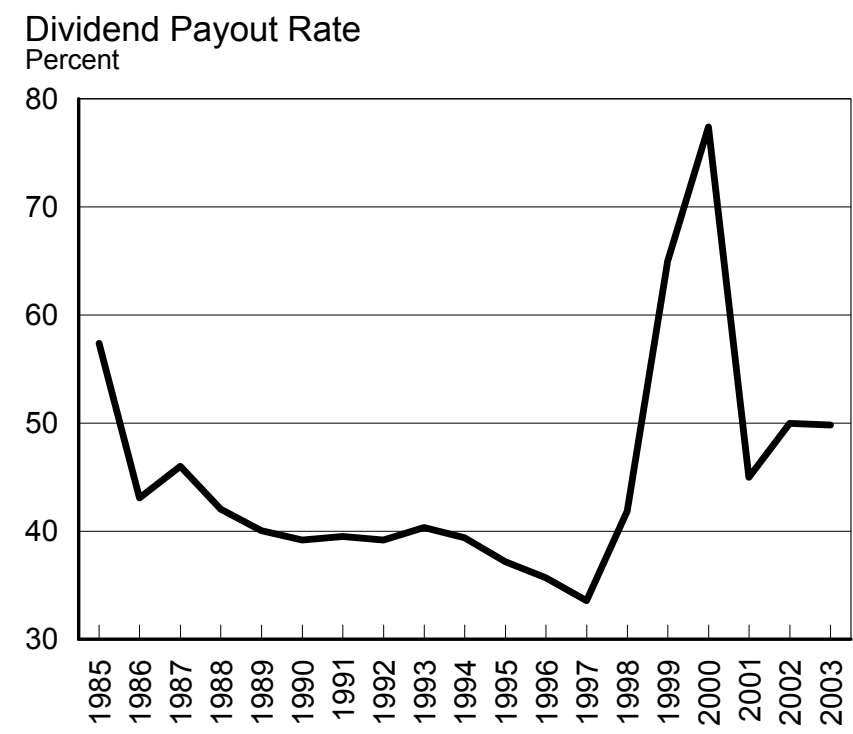

Book Value per Share Dollars

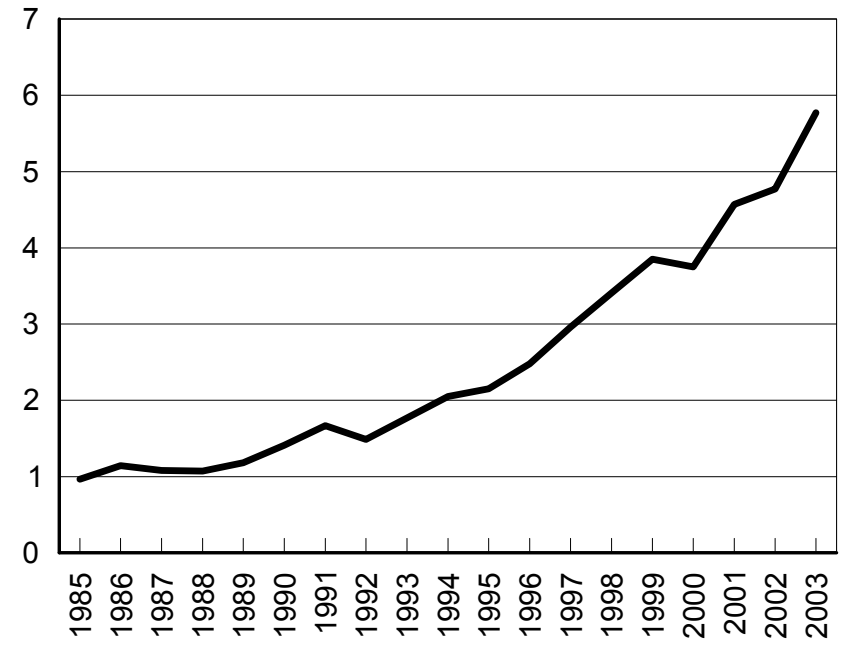

Source: Compustat

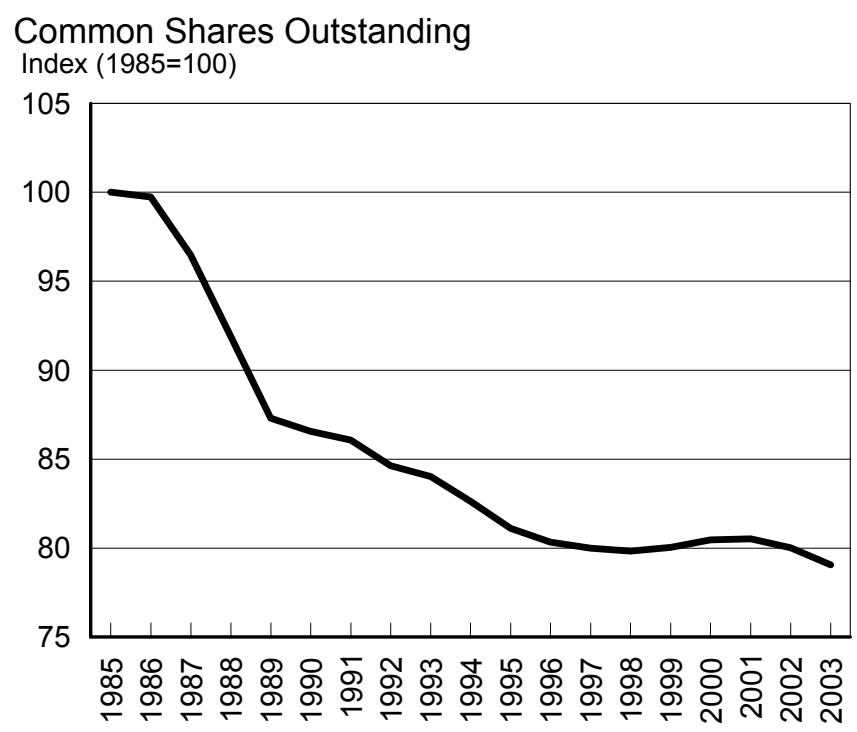

Dividend to Book Capital (solid line) Net Stock Purchases to Book Capital (dashed line)
Percent

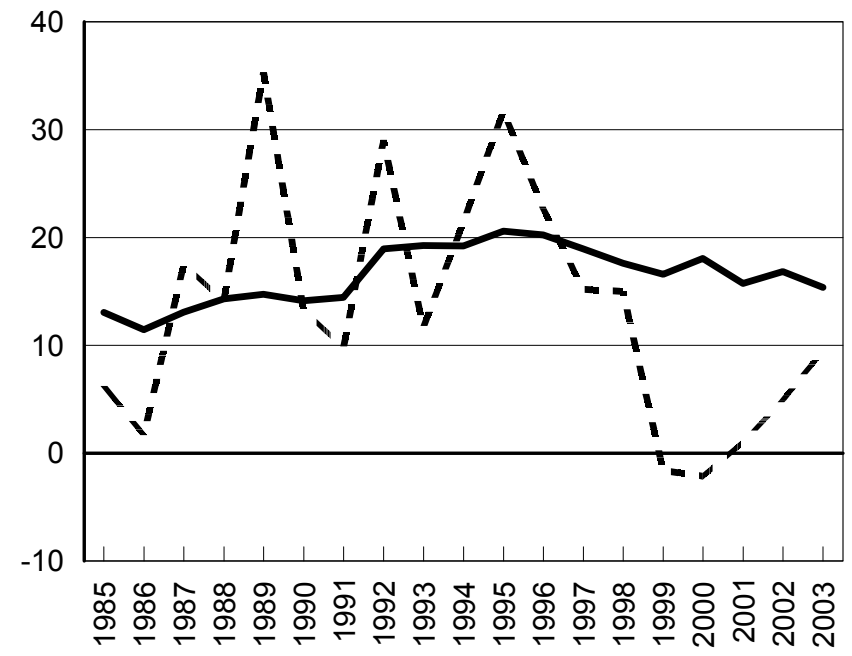




\section{Chart 7}

\section{General Electric Company}
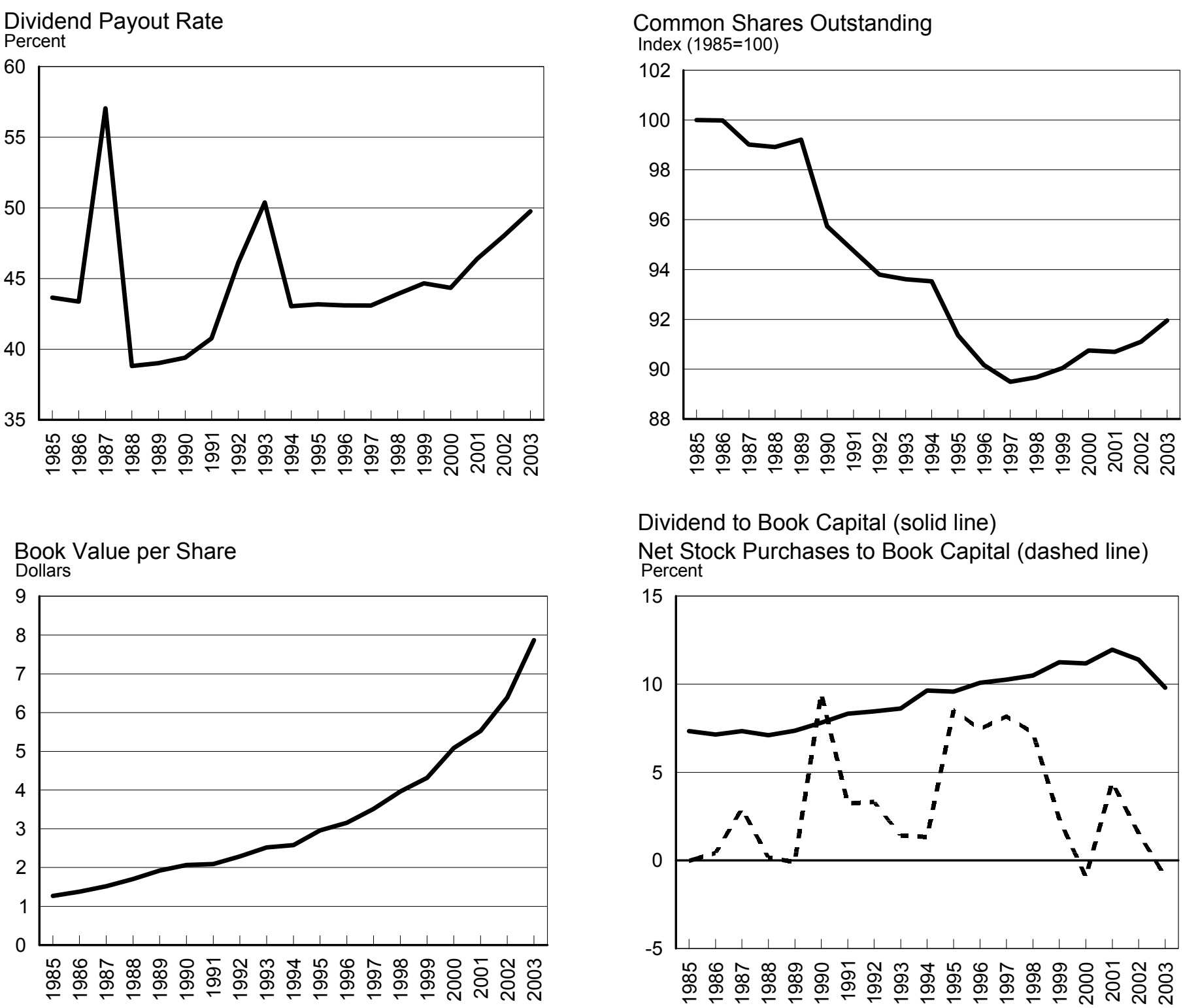

Dividend to Book Capital (solid line)

Net Stock Purchases to Book Capital (dashed line) Percent

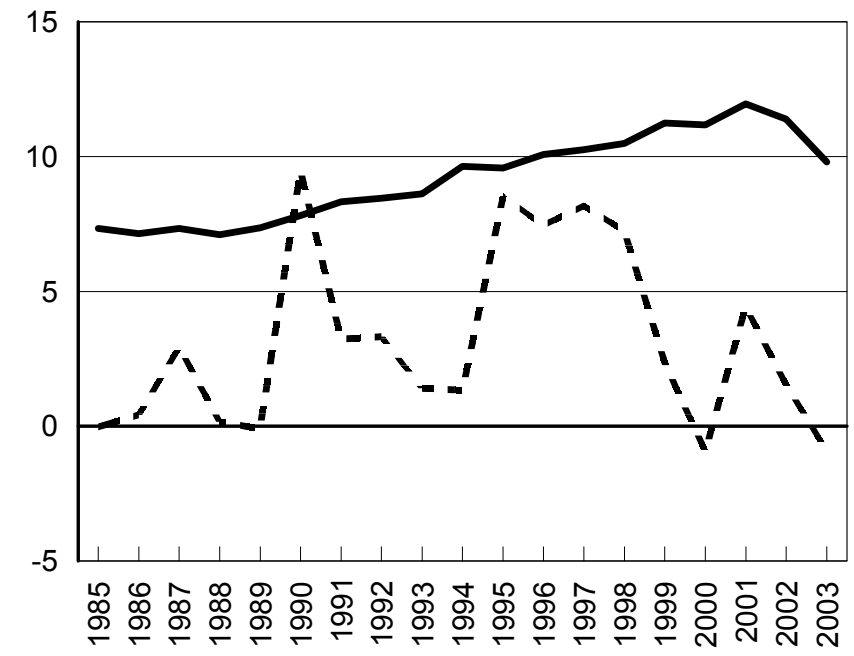

Source: Compustat 


\section{Chart 8}

\section{IBM Corporation}

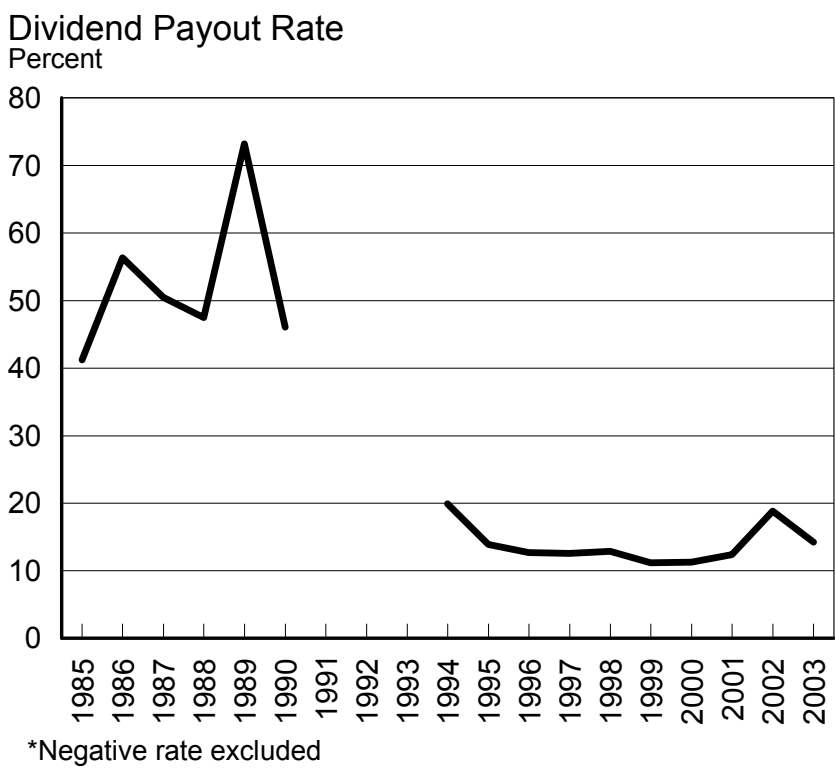

Book Value per Share
Dollars

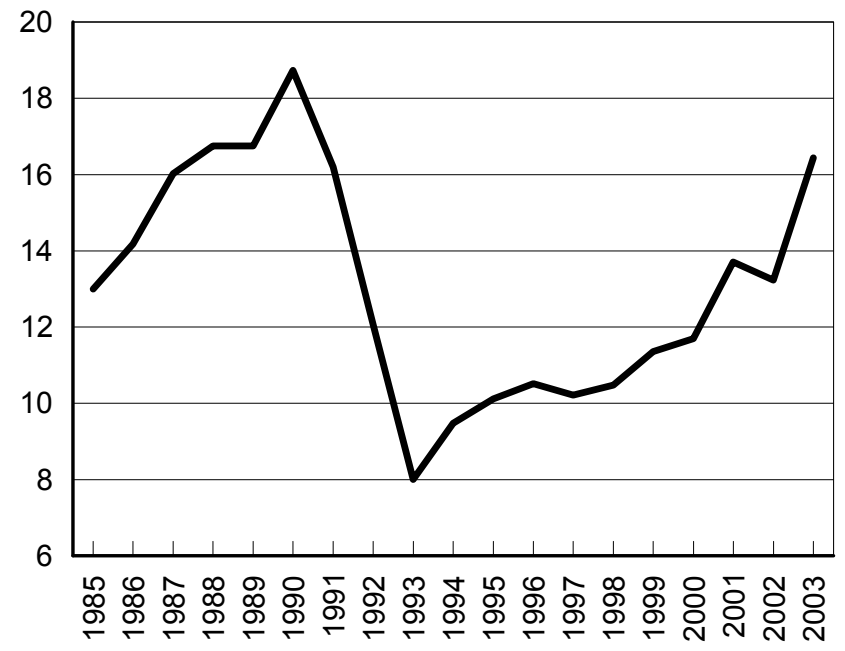

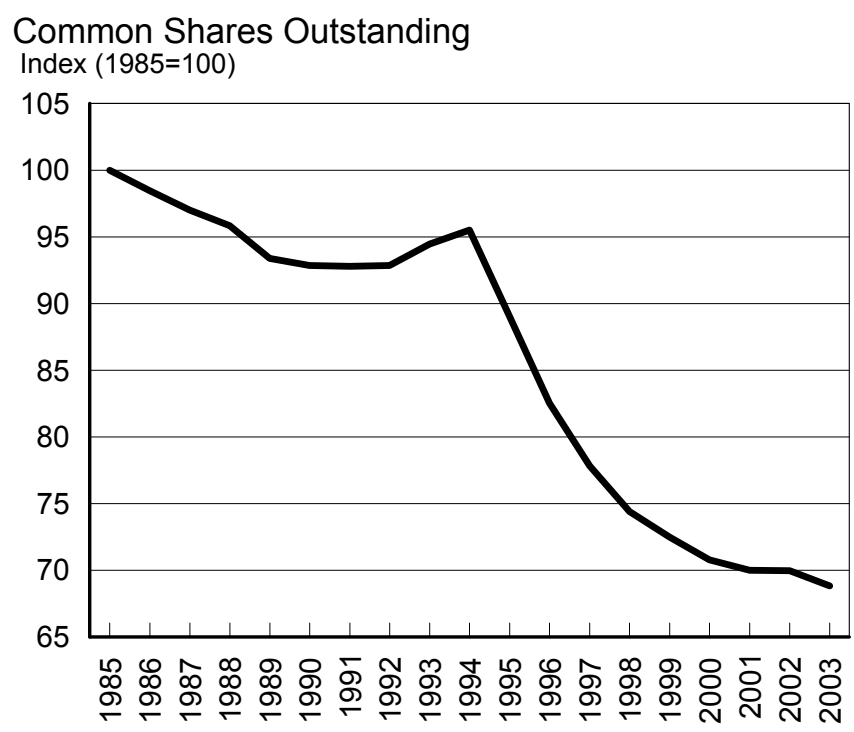

Dividend to Book Capital (solid line) Net Stock Purchases to Book Capital (dashed line)
Percent

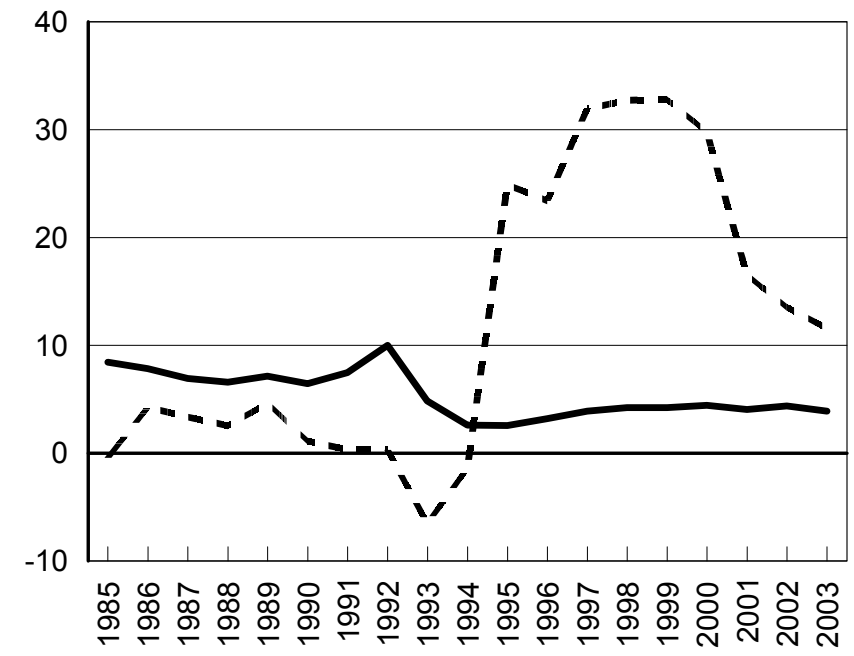

Source: Compustat 


\section{Chart 9}

\section{Oracle Corporation}

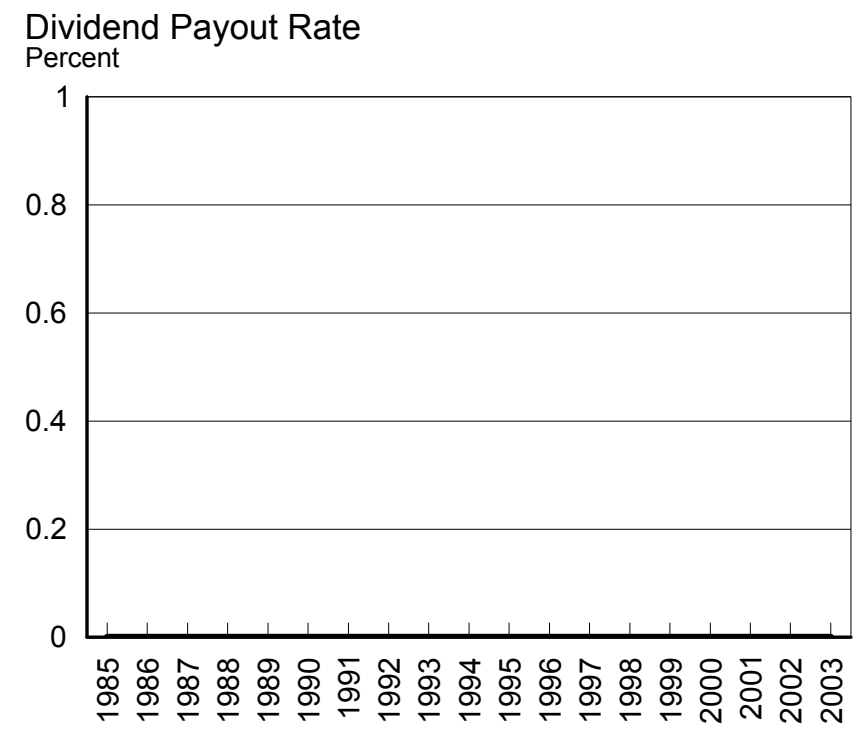
Book Value per Share
Dollars

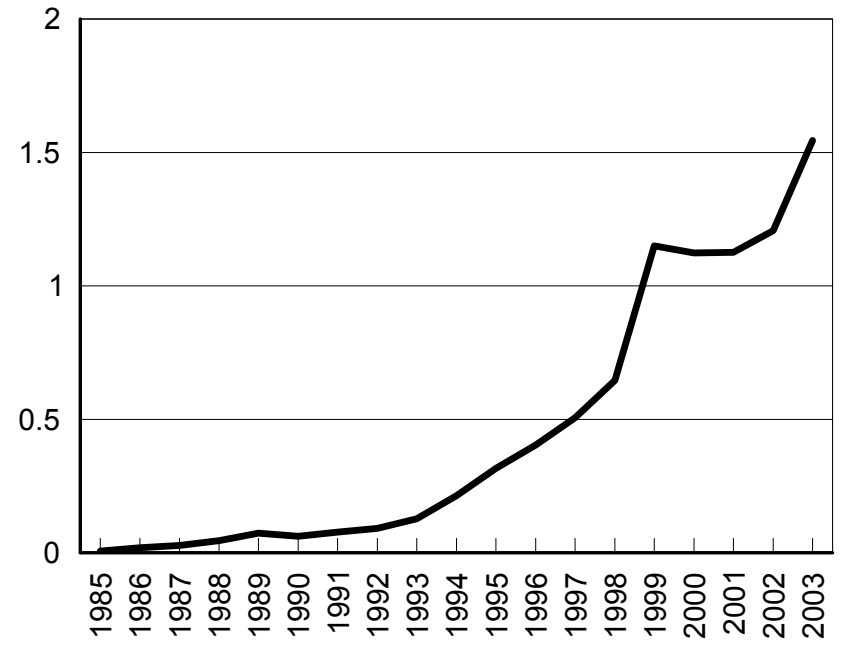

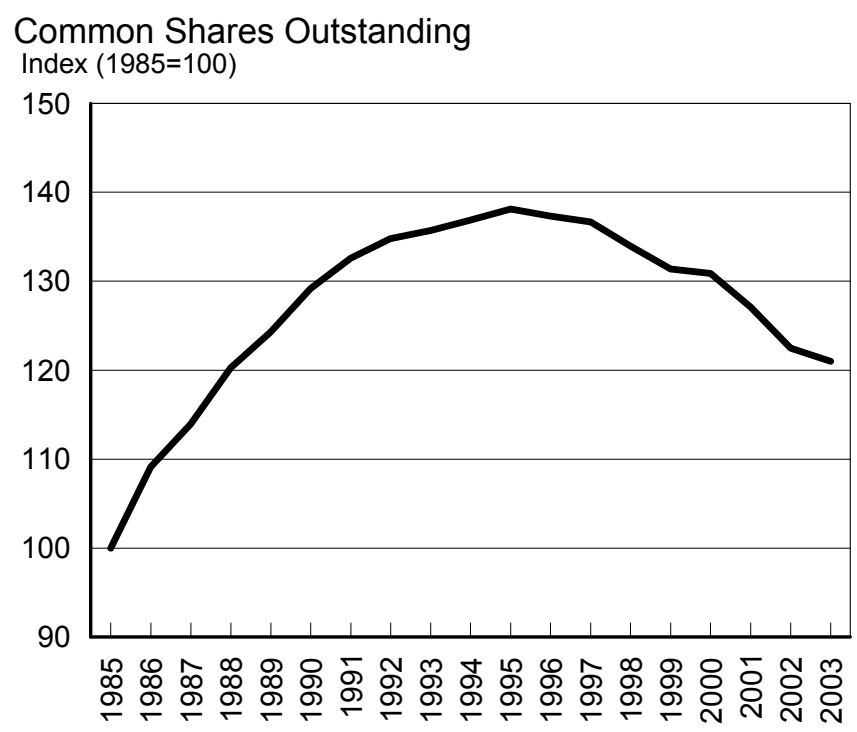

Dividend to Book Capital (solid line) Net Stock Purchases to Book Capital (dashed line)
Percent

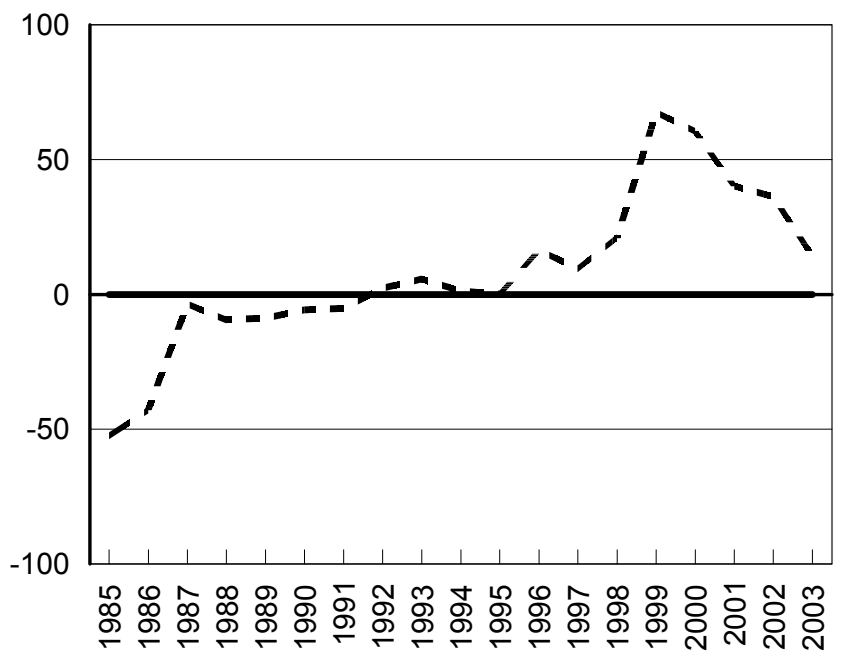

Source: Compustat 


\section{Chart 10}

\section{Federated Department Stores}

Dividend Payout Rate

Percent

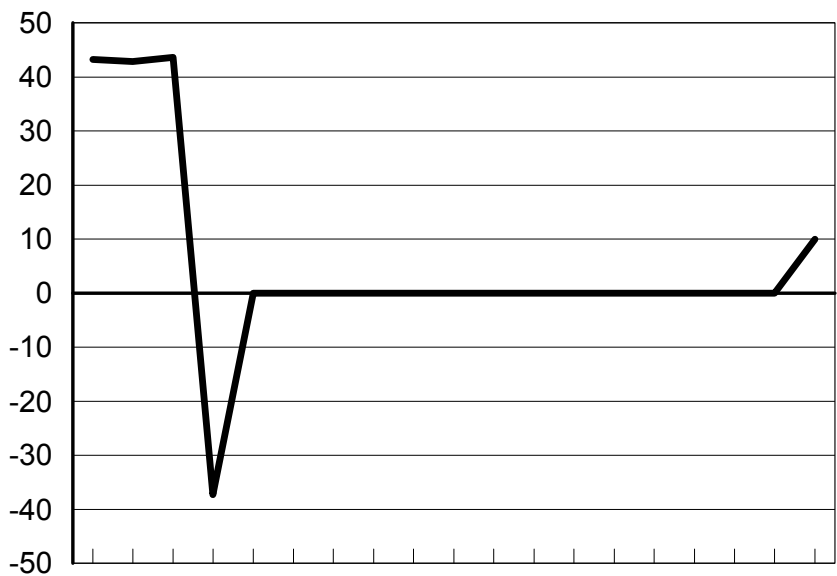

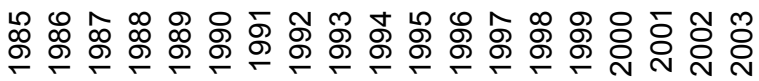

\section{Book Value per Share}

Dollars

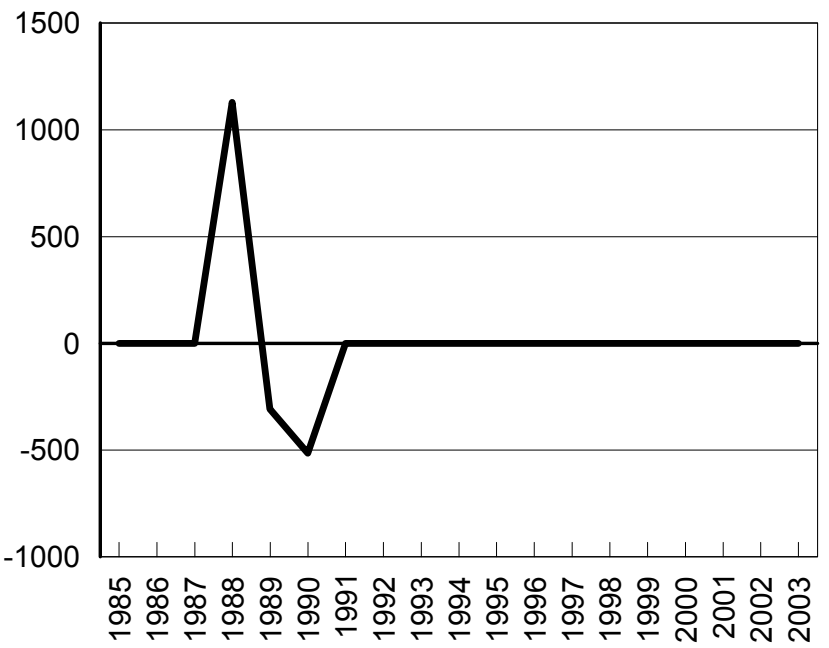

Common Shares Outstanding

Index $(1985=100)$

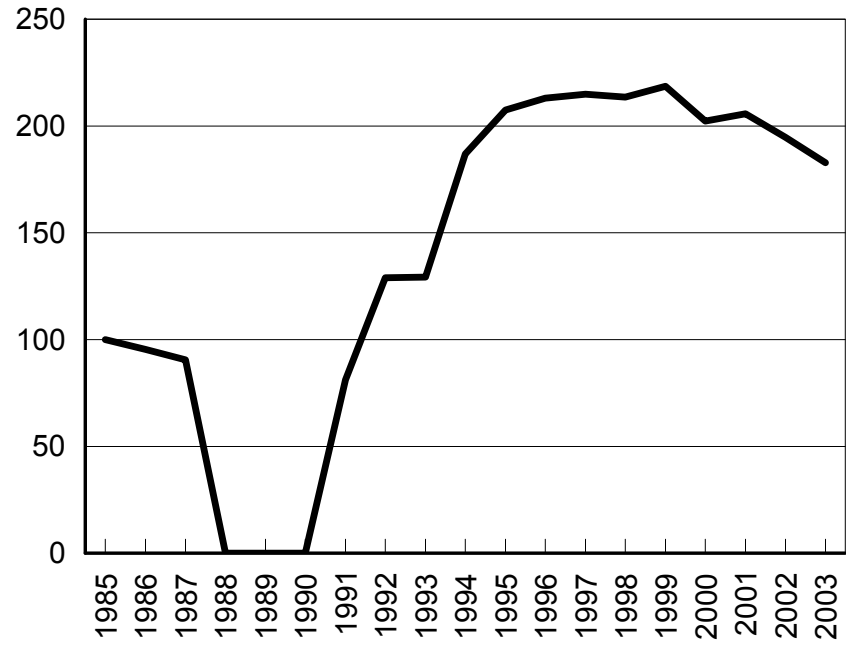

Dividend to Book Capital (solid line)

Net Stock Purchases to Book Capital (dashed line) Percent

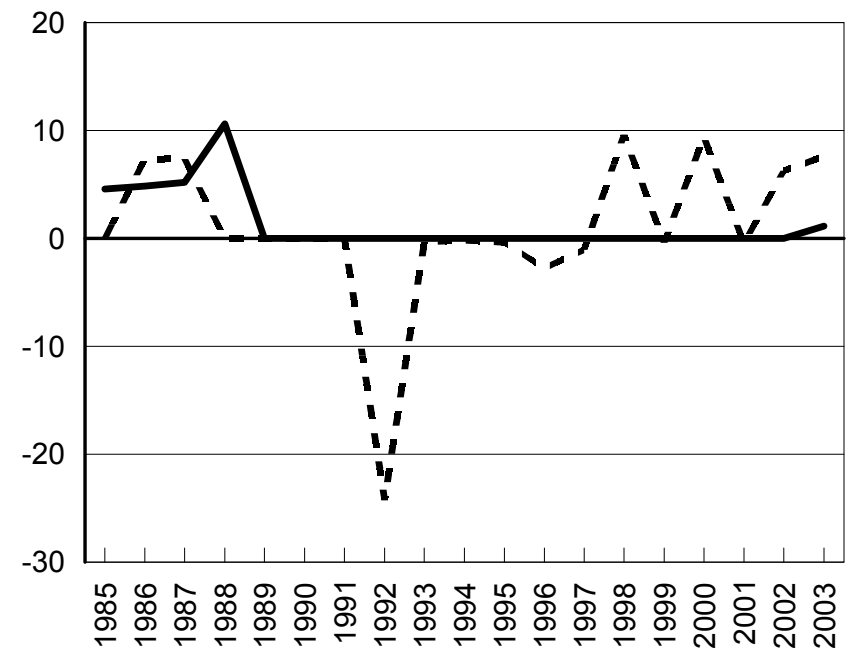

Note: Federated Department Stores underwent Chapter 11 bankruptcy proceedings in the late 1980s and thus experienced negative dividend payouts and market value as well as an absence in outstanding shares during this period.

Source: Compustat 


\section{Chart 11}

\section{International Game Technology}

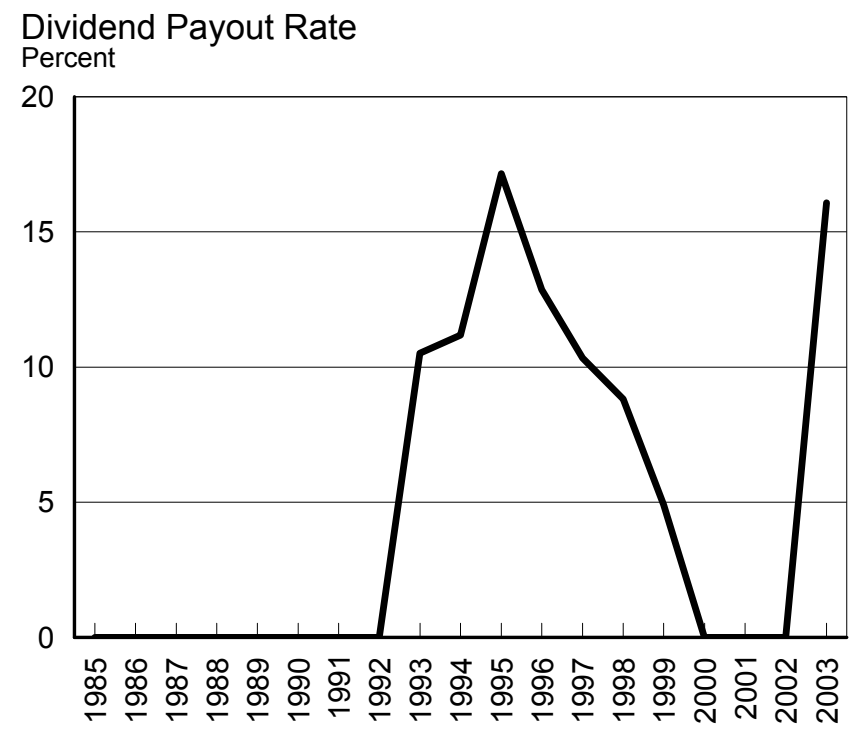

Book Value per Share Dollars

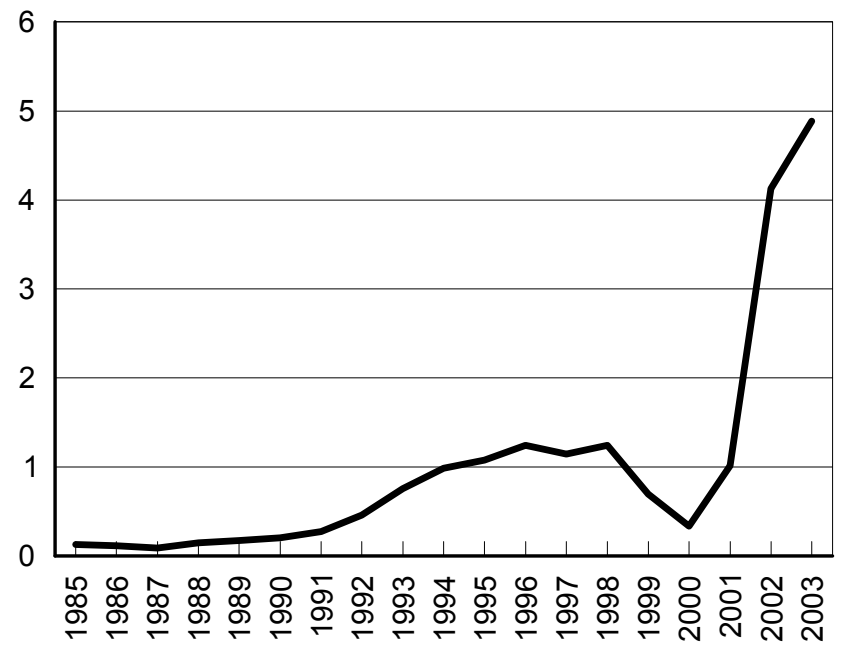

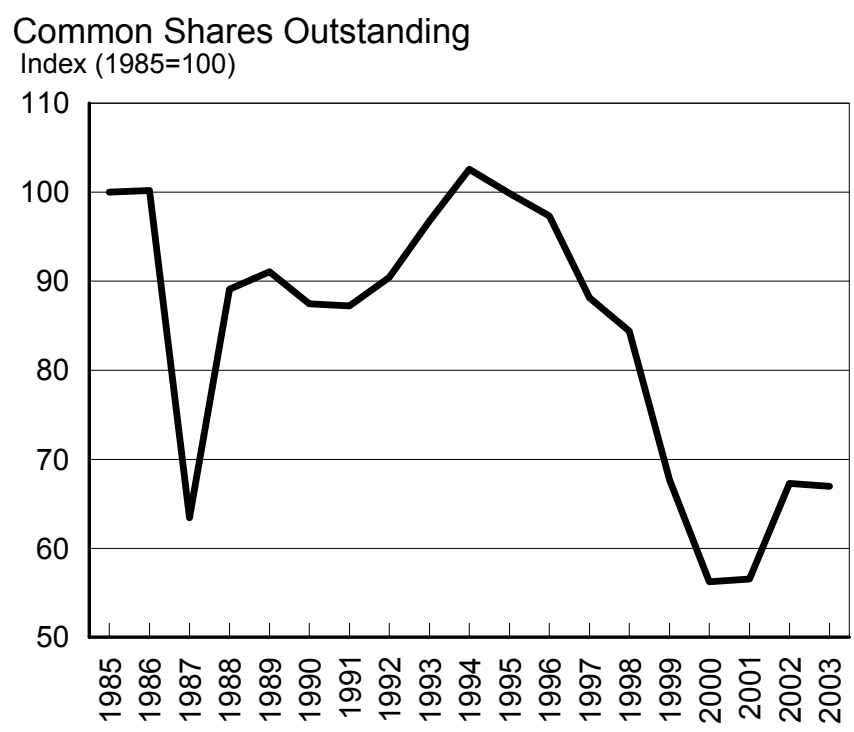

Dividend to Book Capital (solid line)

Net Stock Purchases to Book Capital (dashed line) Percent

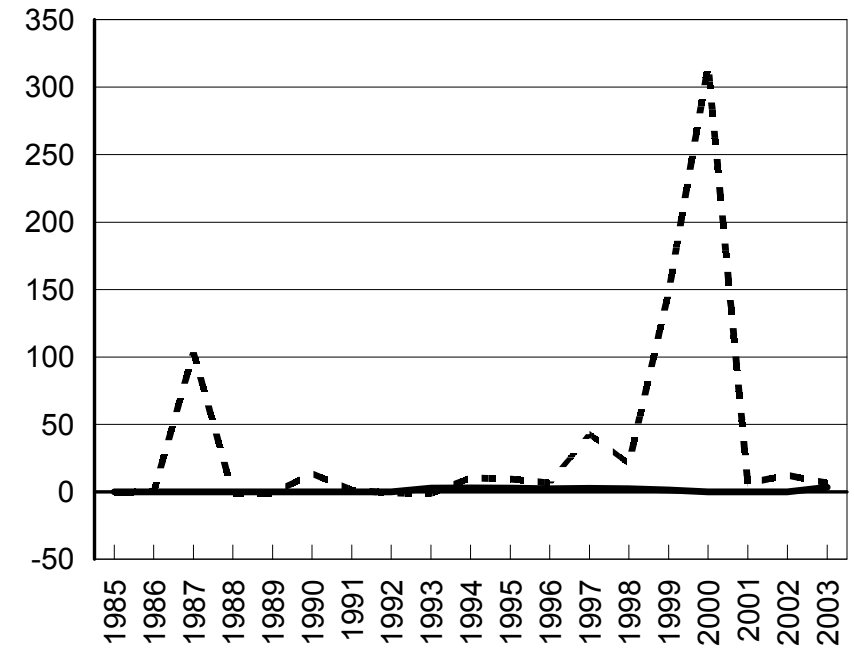

Source: Compustat 


\section{Chart 8}

\section{IBM Corporation}

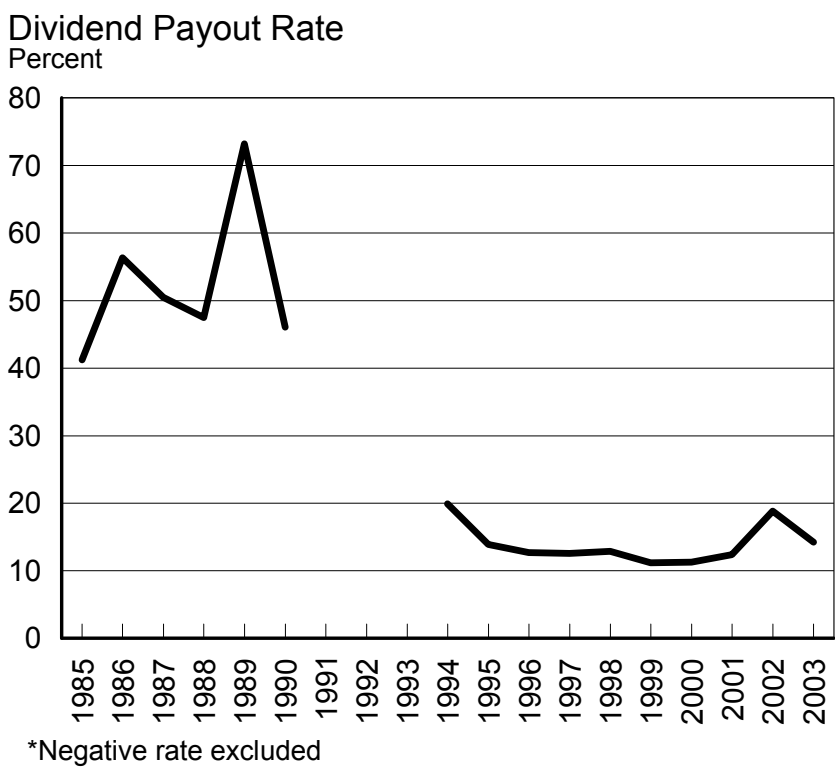

Book Value per Share
Dollars

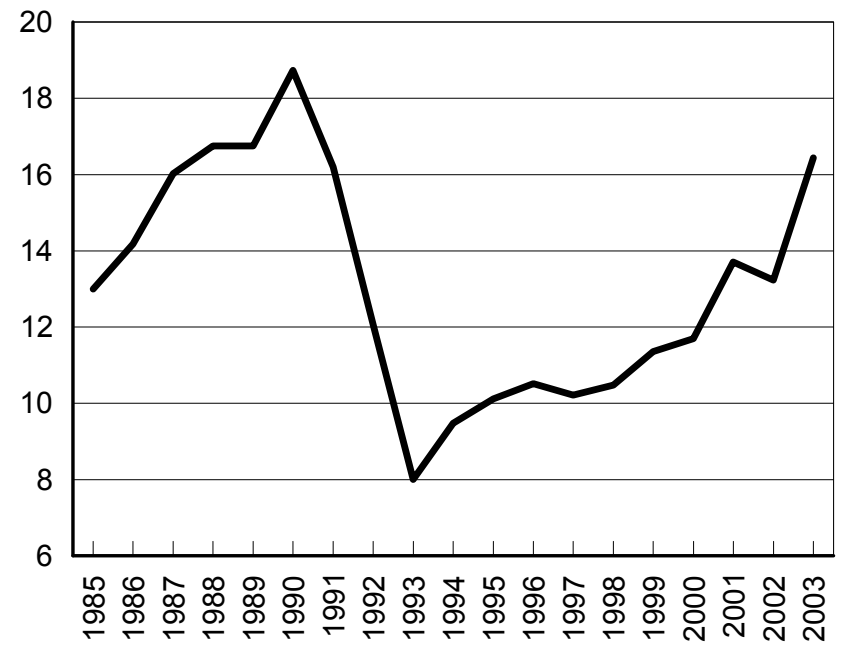

Common Shares Outstanding

Index (1985=100)

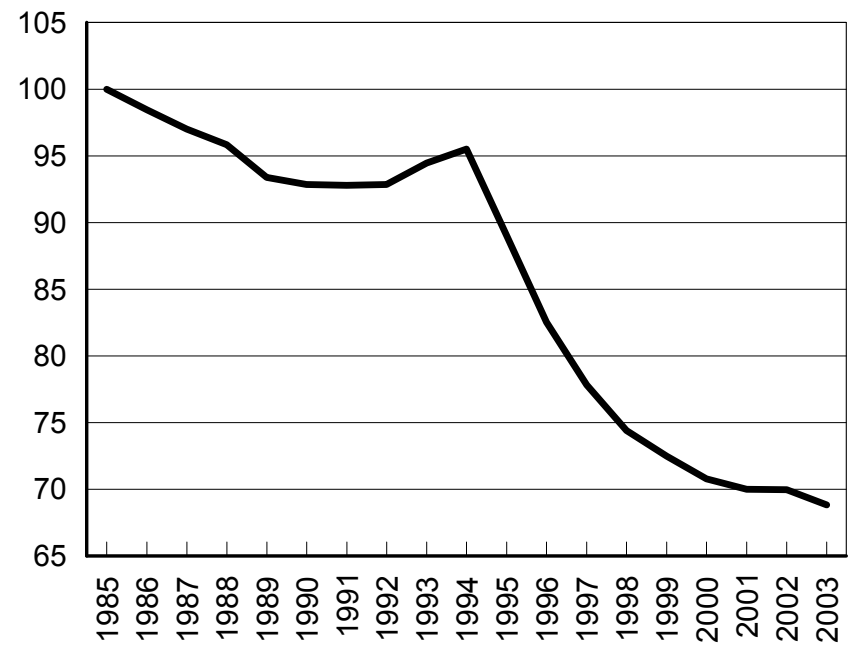

Dividend to Book Capital (solid line) Net Stock Purchases to Book Capital (dashed line)
Percent

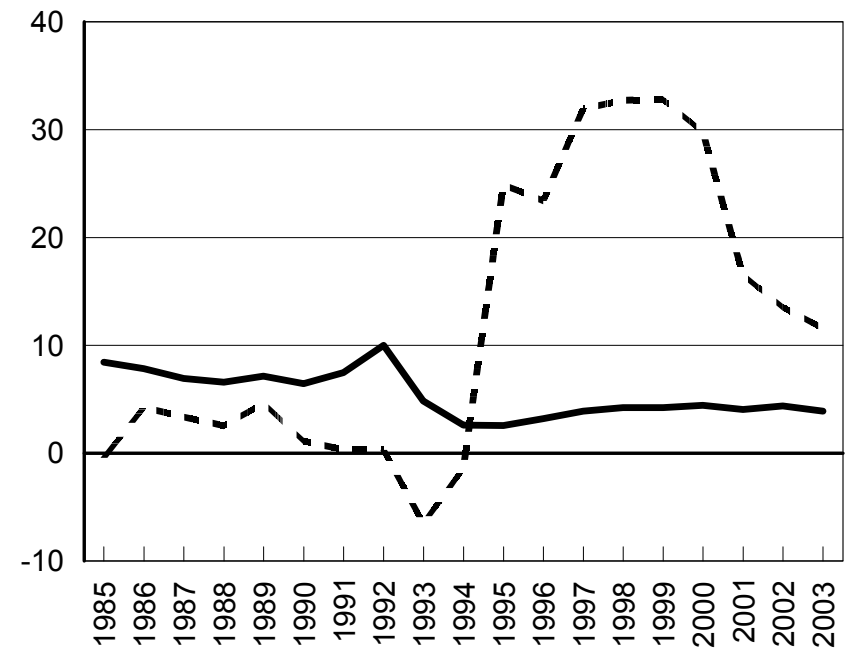

Source: Compustat 


\section{Chart 9}

\section{Oracle Corporation}

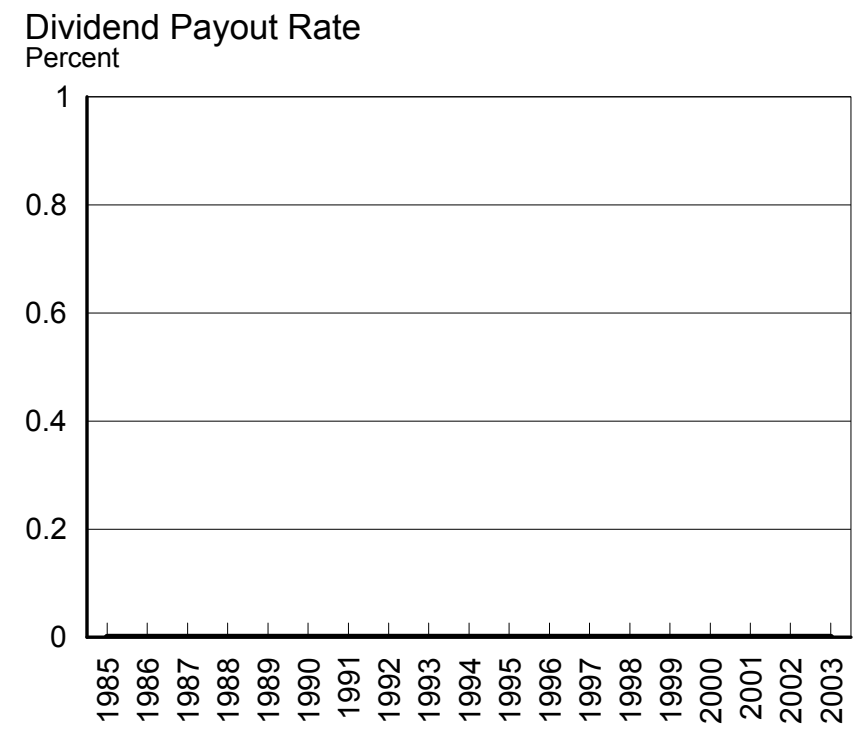
Book Value per Share
Dollars

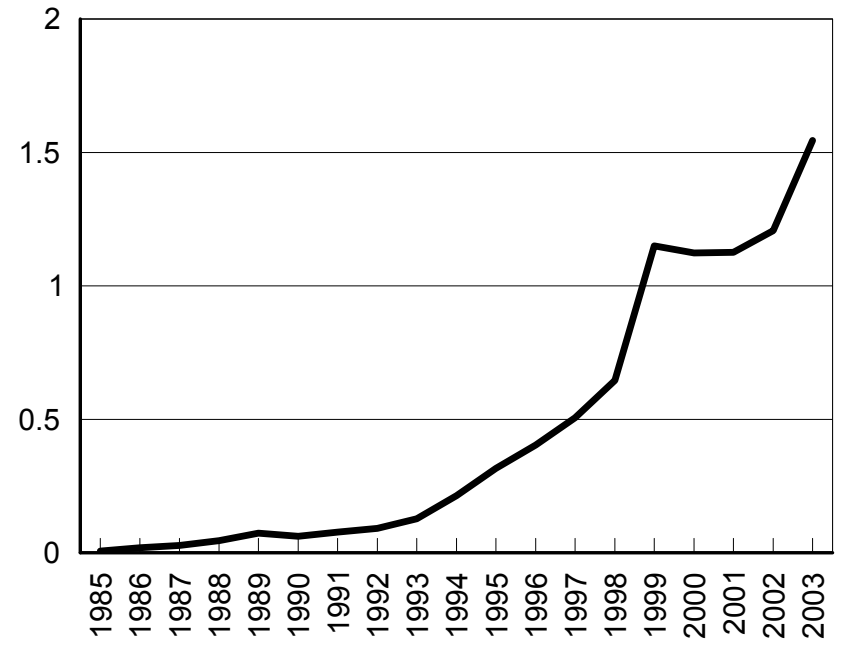

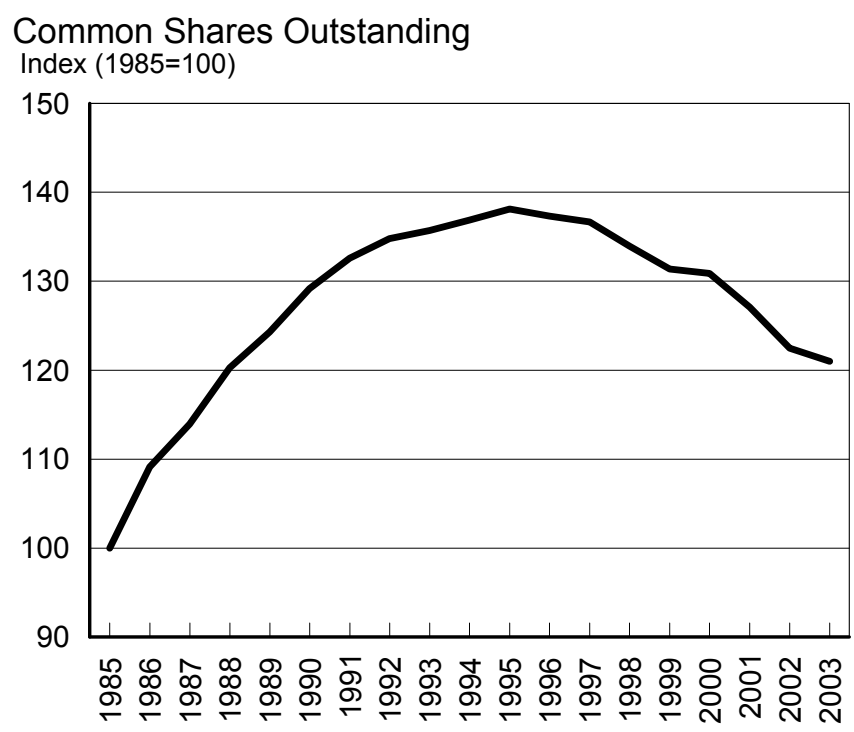

Dividend to Book Capital (solid line) Net Stock Purchases to Book Capital (dashed line)
Percent

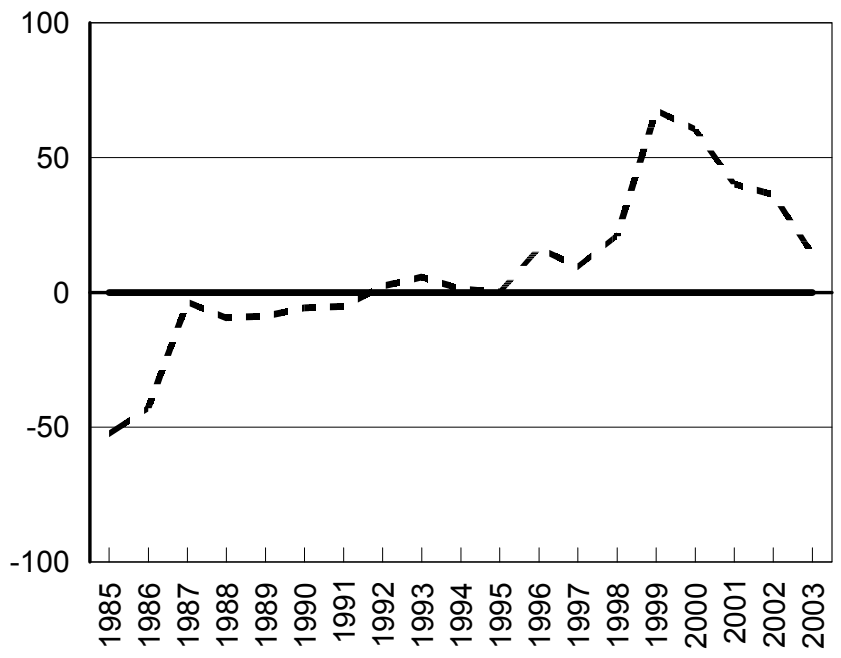

Source: Compustat 


\section{Chart 10}

\section{Federated Department Stores}

Dividend Payout Rate

Percent

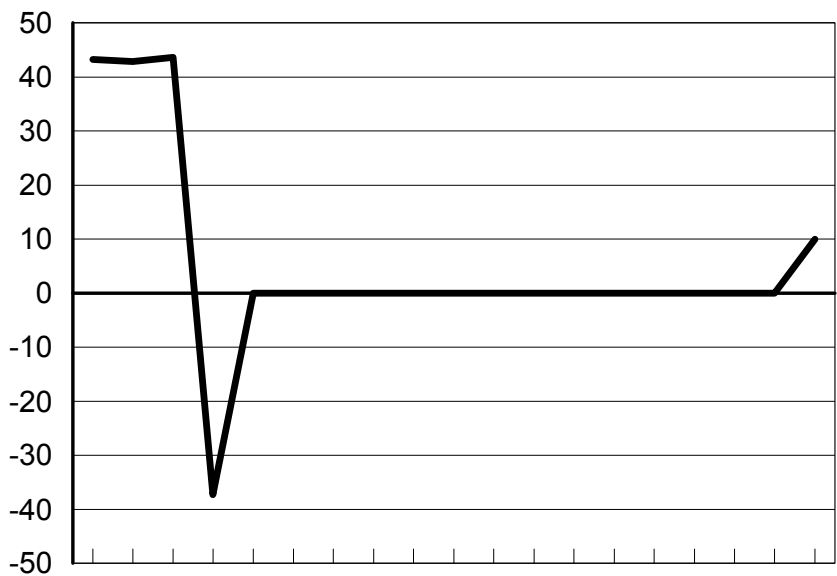

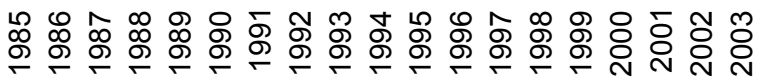

\section{Book Value per Share}

Dollars

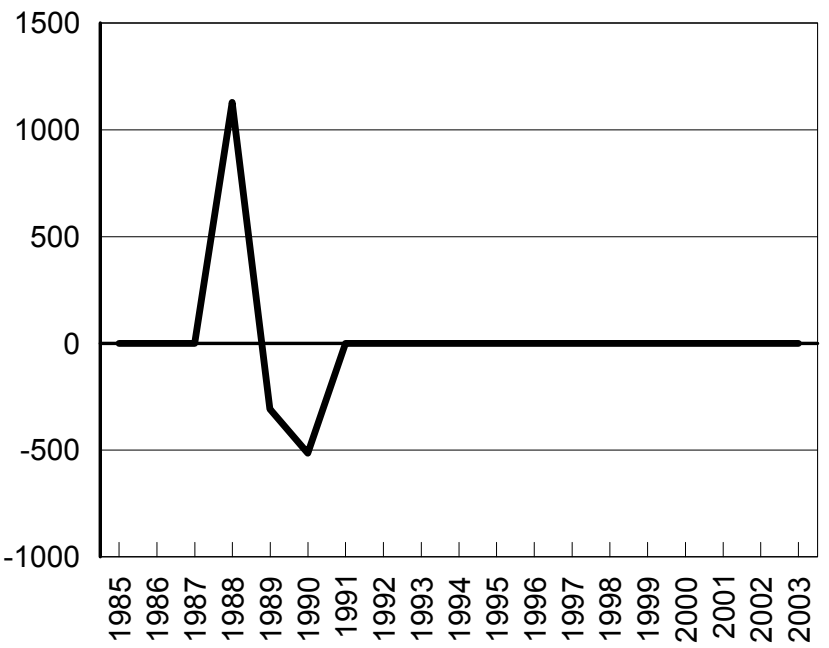

Common Shares Outstanding

Index $(1985=100)$

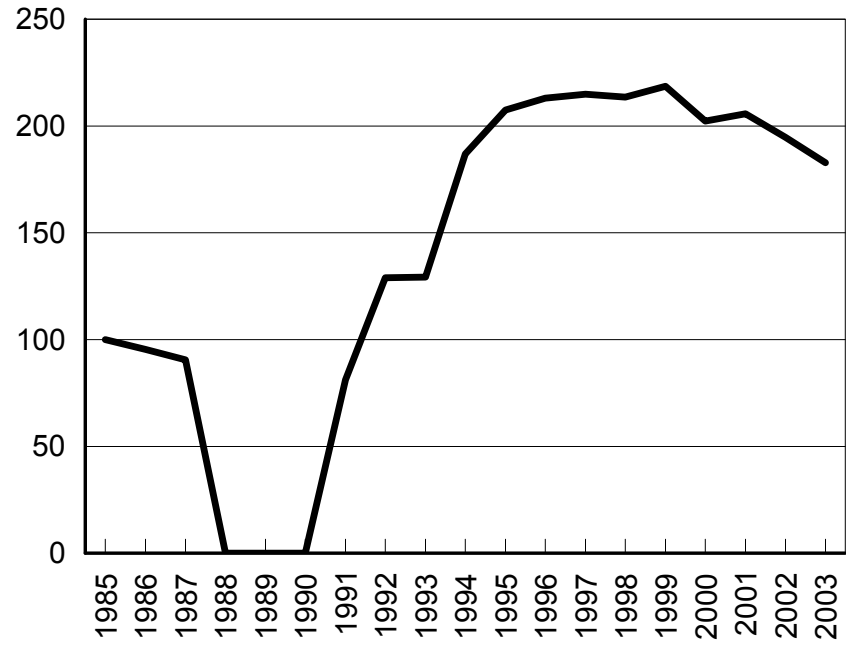

Dividend to Book Capital (solid line)

Net Stock Purchases to Book Capital (dashed line) Percent

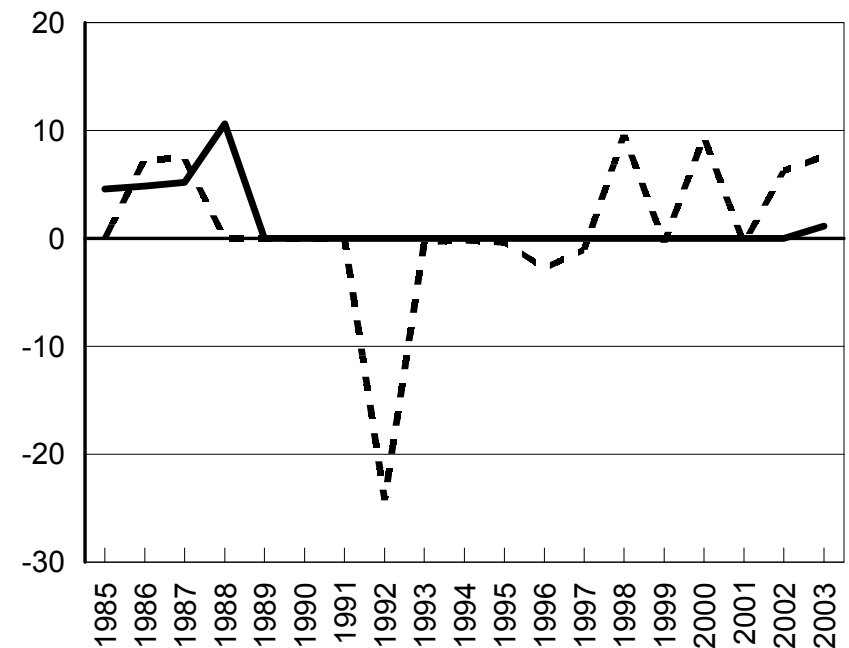

Note: Federated Department Stores underwent Chapter 11 bankruptcy proceedings in the late 1980s and thus experienced negative dividend payouts and market value as well as an absence in outstanding shares during this period.

Source: Compustat 


\section{Chart 11}

\section{International Game Technology}
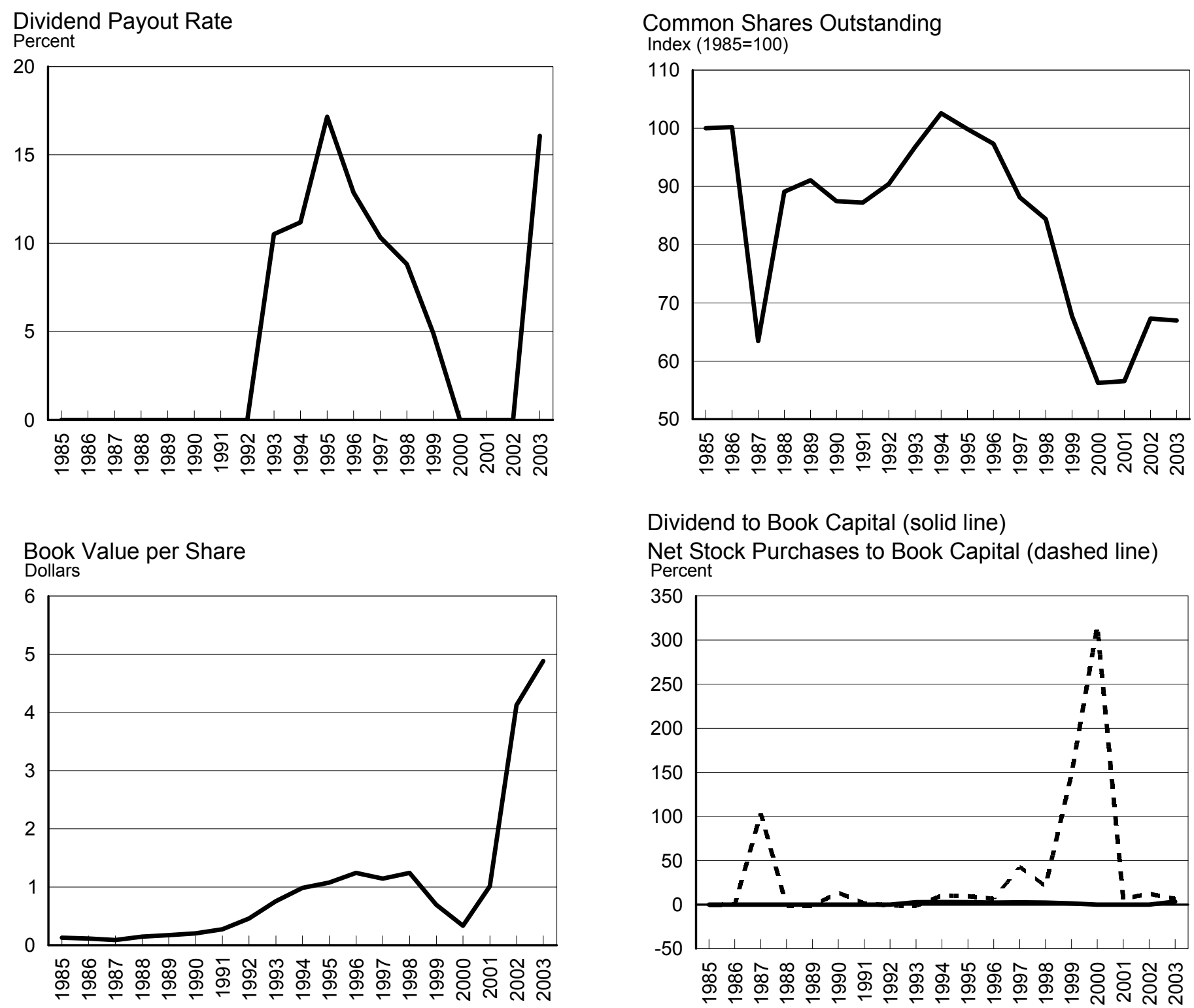

Dividend to Book Capital (solid line)

Net Stock Purchases to Book Capital (dashed line) Percent

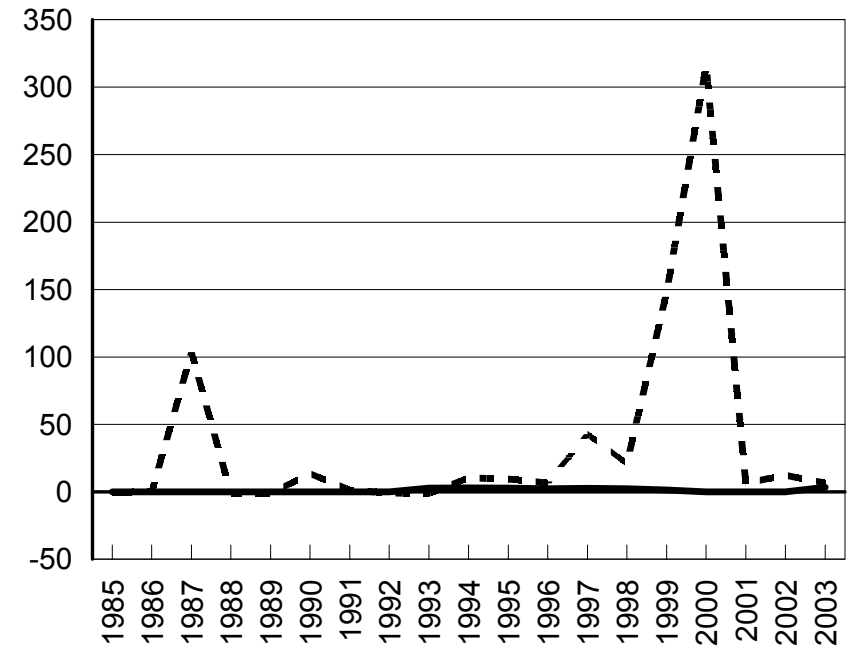

Source: Compustat 